\title{
New insights on the late Quaternary geologic evolution of the Ischia Island coastal belt based on high-resolution seismic profiles
}

\author{
Gemma Aiello
}

\begin{abstract}
The study of the seismo-stratigraphic architecture of late Quaternary-Holocene volcanic and sedimentary units in the Ischia Island offshore and their correlation with the coastal units of the adjacent onshore sectors allowed for a detailed reconstruction of the seismic stratigraphy of the northern, southern and western sectors of the island. Five (southern Ischia) to nine (western Ischia) seismic units and related seismic facies were identified. The volcanic areas and their detailed seismo-stratigraphic setting fit well in the geological context of a passive margin and confirm that the stratal architecture in the Ischia Island Quaternary marine deposits is controlled by the interaction between glacio-eustatic fluctuations, volcanism, tectonics and sedimentary supply.
\end{abstract}

KEY WORDS: seismic interpretation, Ischia Island, sea cliffs, beaches, Naples Bay.

\section{INTRODUCTION}

The main goals of this paper include the reconstruction of the seismo-stratigraphic architecture of late Quaternary-Holocene volcanic and sedimentary seismic units in the Ischia Island offshore and their correlation with the coastal units of the surrounding onshore sectors, focusing, in particular, on the underwater distribution of the late Quaternary depositional sequence and the seismic characterization of the hummocky deposits occurring in the north-western sectors. The expected results comprise a detailed seismic stratigraphy of the northern, southern and western sectors of the Ischia Island and may be compared with those ones obtained from geological researches in this (BRUno et alii, 2002; Violante et alii, 2003; D'ARgEnIO et alii, 2004; CoRradi et alii, 2009; DE ALTERIIS et alii, 2010; GIORDANO et alii, 2013) and other volcanic Mediterranean marine areas (CHIocci et alii, 1997; FACCENNA et alii, 1997; CARMINATI et alii, 1998; FACCENNA et alii, 2001; Rollet et alii, 2002; SARTORI, 2003; Bruno, 2004; Lastras et alii, 2004; SARTORI et alii, 2004; CONTI et alii, 2017).

One main aim of this paper is to present new data on the late Quaternary geologic evolution of the Island of Ischia through the interpretation of seismic profiles correlated with the coastal geology of corresponding sectors. A detailed geological study has been carried out focusing on some selected sectors of the Ischia Island coastal belt, including both high tuff coastal cliffs, such as Succhivo and

Istituto per l'Ambiente Marino Costiero (IAMC), Consiglio Nazionale delle Ricerche (CNR), Calata Porta di Massa, Porto di Napoli, 80133, Napoli, tel. 0815423820, fax 0815423888.

Corresponding author e-mail: gemma.aiello@iamc.cnr.it.
Punta dello Schiavo (Fig. 1) and low sandy littorals, characterized by the development of important beaches ("Spiaggia degli Inglesi" and "Cava dell'Isola"; Fig. 1). In particular, four sectors have been selected based on their geological and geomorphological characteristics coupled with the availability of seismic data and represented in the sketch geological map of Fig. 1, while Fig. 2 reports the navigation map of the seismic profiles shown in this paper. The first area is distinguished from the Succhivo coastal cliff onshore, occurring in the southern coastal belt westwards of the Sant'Angelo Promontory and by the L39 seismic line, recorded in the surrounding offshore (Fig. 1). The second area is located in correspondence with the coast from the Ischia harbor to the "Spiaggia degli Inglesi" beach, located in northern Ischia and the surrounding offshore, crossed by the L26 Sparker line (Fig. 1). The third sector is distinguished from the coast of western Ischia next to the "Cava dell'Isola" beach and the adjacent offshore, investigated through the Sparker line L33 (Fig. 1). The fourth sector is characterized by the tuff coastal cliff of Punta dello Schiavo, located at south-western Ischia and its offshore, which has been crossed by the Sparker line L37 (Fig. 1).

While previous papers on Ischia Island based on the same dataset (Aiello et alii, 2012; Aiello \& MARsella, 2014) are mainly focused on the seismic sections of southern and eastern sectors at the join with Procida, this paper is aimed at improving the geological knowledge of northern and western sectors of the island and at highlighting the distribution of submarine debris avalanche deposits in the north-western offshore based on seismic data. Moreover, geological examples on the south-western Ischia continental slope and the surrounding tuff coastal cliffs have been studied.

New insights are herein proposed on the coastal belt of Ischia Island referring both to high tuff coastal cliffs, representing high rocky coasts and to low coasts with sandy beaches through the integrated study of seismic sections and surrounding emerged areas. The Ischia Island coast is divided into two main zones: the northern part is articulated in hills, while the southern one is characterized by the occurrence of cliffs, mountains and bays bounded by promontories. Ischia is the most important city of the homonymous island, divided in an oldest town, namely Ischia Ponte and a modern town, namely Ischia Porto. Important localities, representing different morphological and physiographic domains have been distinguished and described (MonTI, 2011; SBRANA et alii, 2011).

The tracts of rocky coasts of the Ischia Island correspond to erosional surfaces, produced during the Quaternary as a result of the relationships between volcanic 


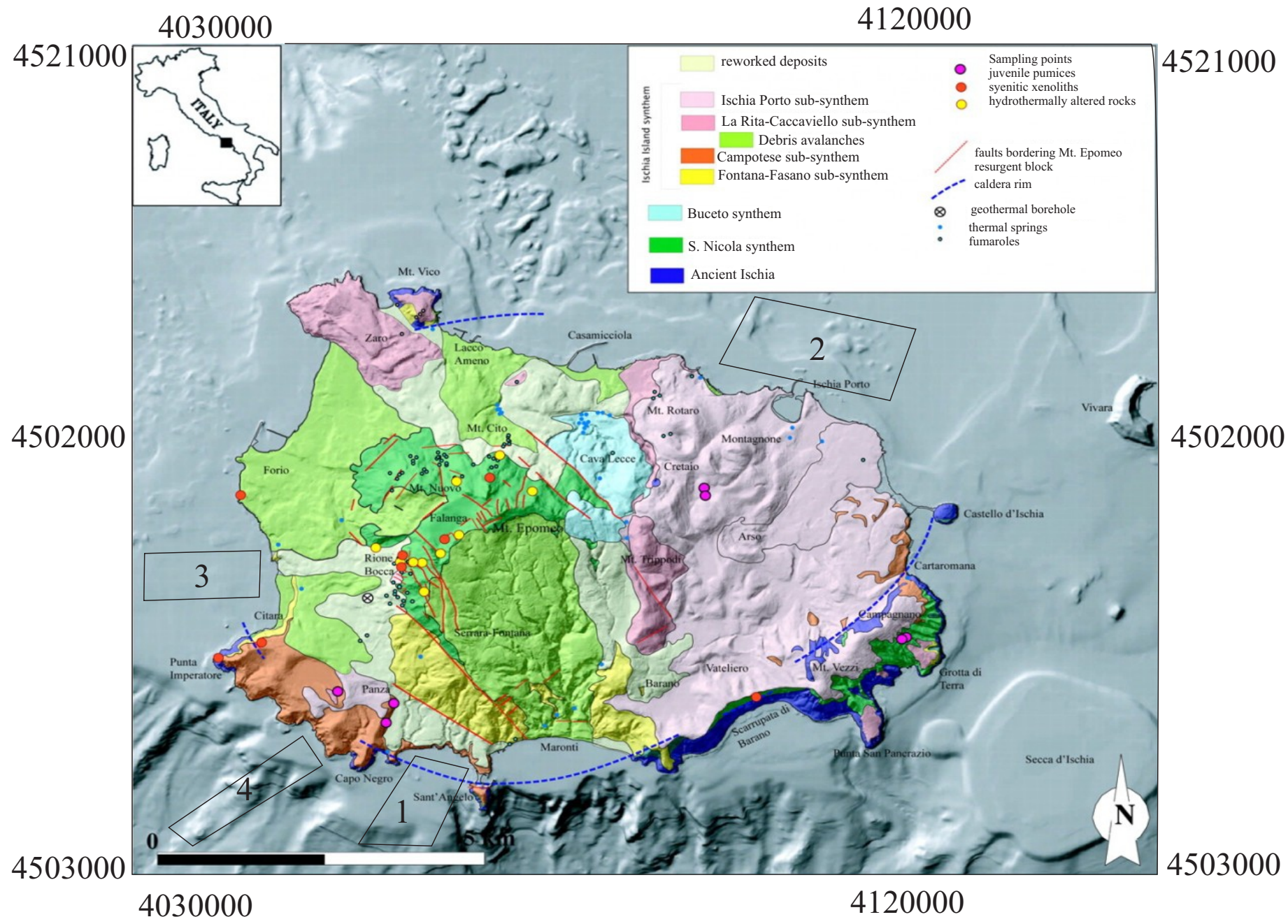

Fig. 1 - Geological map of Ischia Island (http://www.napoliunplugged.com/ischia-growing-up-is-hard-to-do.html) superimposed on shaded relief map of the Ischia Island showing the location of the four selected sectors studied in this paper (inset map: location of the Ischia Island in Italy). 1, Succhivo coastal cliff/L39 Sparker line (southern Ischia coastal belt); 2, "Spiaggia degli Inglesi" beach (Ischia harbor)/L26 Sparker line (northern Ischia offshore); 3, "Cava dell'Isola" beach (Forio d'Ischia) and corresponding coastal cliff (western Ischia offshore)/L33 Sparker line. 4, Punta dello Schiavo coastal cliff (Panza)/Sparker seismic line L37. Geographic coordinate system is: UTM33, WGS84.

and tectonic processes, sea level eustatic fluctuations and climatic changes. These coasts, together with the adjacent mountains and sea bottoms, represents transition environments, continuously evolving and unstable due to geologic and geomorphologic control factors. Among them the most important control factor in shaping the rocky coasts is represented by the coastal landslides genetically related to the sea action, coupled with the sea wave erosion at the foot of the cliff (scouring) triggering rock falls (EDIL \& Le Vallejo, 1980; Clark et alii, 1996; Cruden \& Varnes, 1996; Hall et alii, 2000; IADANZa et alii, 2009; ABellan et alii, 2010; Bozzano et alii, 2010; Thiebes, 2012).

In this study the coastal cliffs have been analyzed both in the Succhivo and Punta dello Schiavo areas, while main beach systems, corresponding with significant tracts of low sandy coasts have been studied in correspondence with the "Spiaggia degli Inglesi" and "Carta Romana" beaches.

Relevant studies on coastal geomorphology of the Ischia Island have been recently produced in the frame of geological mapping (MonTI, 2011; SBRANa et alii, 2011; PASSARo et alii, 2016). The morpho-structural characterization of the coast- al sea bottoms through the bathymetry has revealed a close relationship between the morpho-bathymetry of the island and the physiographic and structural setting of the adjacent emerged sectors. In some cases, mainly in correspondence with the high coastal cliffs, a large variety of coastal landforms has been observed, controlled by the strong volcanic activity (lava deposits and coarse-grained pyroclastic deposits), by the tectonic activity and by alternating depositional and erosional processes since the Pleistocene. As a general rule, the seaward extension of the coastal geological units may be observed. Moreover, the coastal geomorphological data have evidenced the occurrence of relict morphologies genetically related with old sea level stands, lower than the present-one (SBRANa et alii, 2011). The depth of the marine terraces is suggested to be at 3, 5, 10, 20 and $30 \mathrm{~m}$ below the present-day sea level. Coarse-grained deposits are often disposed at the foot of tectonically-controlled palaeo-costal cliffs, representing relict deposits, not in equilibrium with the current depositional processes.

A Digital Elevation Model (DEM) of Ischia Island has been constructed (Fig. 3) in order to show the location of 


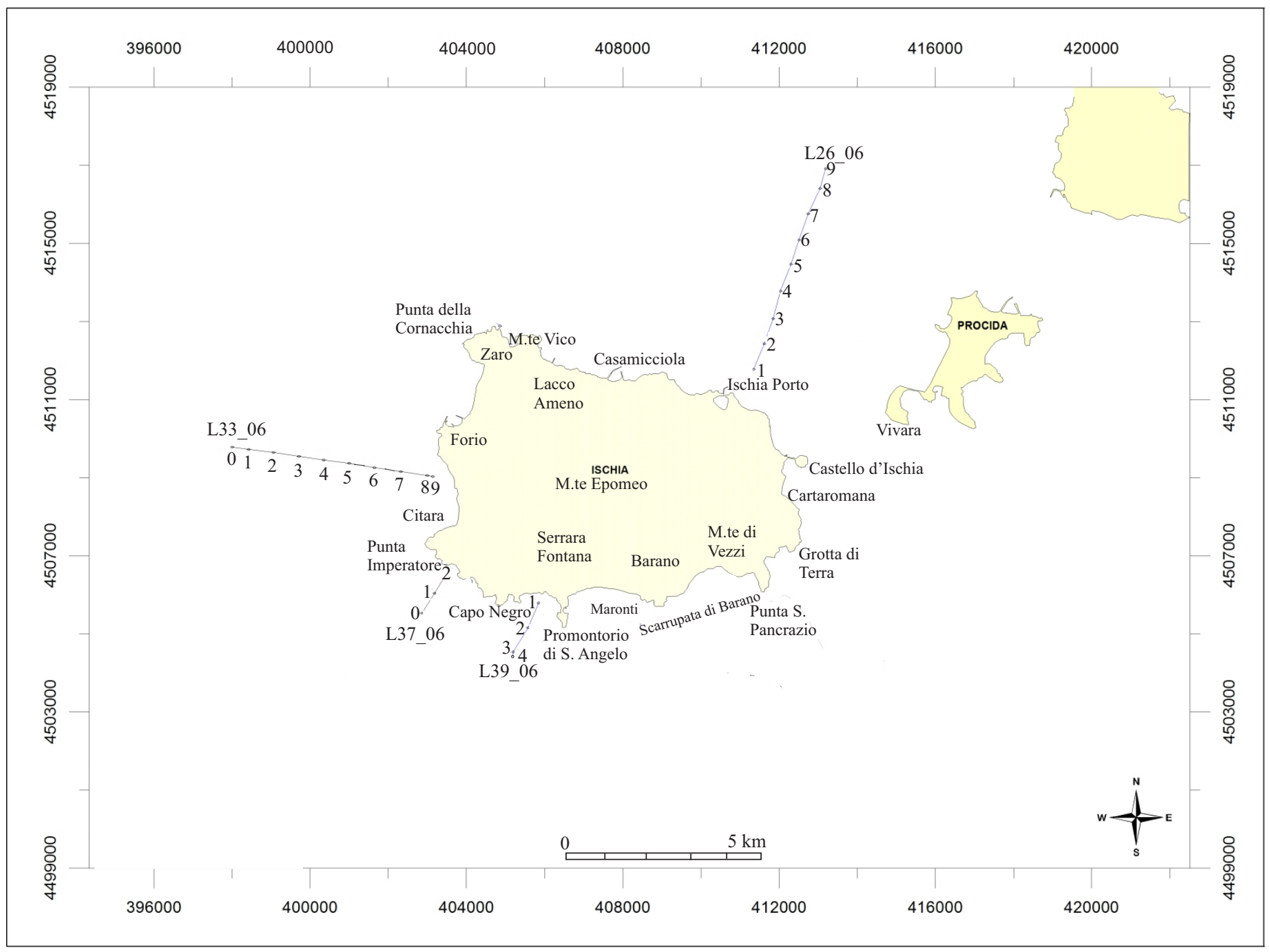

Fig. 2 - Navigation map of the seismic lines interpreted in this paper. Geographic coordinate system is: UTM33, WGS84.

the study areas as reported on the Ischia morpho-bathymetric setting (Fig. 1). Main localities and toponyms cited in this paper have also been reported in order to facilitate the comprehension of the text and corresponding references (Figs. 1-3). The location of the Sparker seismic lines on the Multibeam bathymetric data has revealed the occurrence of significant morpho-structures, outcropping along the sea bottom (Fig. 3).

\section{GEOLOGIC SETTING}

The Tyrrhenian Sea represents an extensional area located in a compressional setting, whose extension started about $10 \mathrm{My}$ ago, leading to the formation of oceanic lithosphere during the Pliocene (Patacca \& SCANDONE, 1989; SARTori, 2003; Doglioni et alii, 2004; MatTei et alii, 2004; Lustrino \& Wilson, 2007; Cloetingh et alii, 2008; Aiello et alii, 2014). Three continental margins, i.e. the Sardinia margin, the Northern Sicily margin and the Southern Italy margin bound the Southern Tyrrhenian bathyal plain. This area is characterized by active seismicity and volcanism and has undergone strong horizontal and vertical move- ments. A narrow and deep Benioff zone, extending from the Ionian sea to the Tyrrhenian Sea marks the occurrence of an eastward migrating subduction plane (SARTORI, 2003).

The Naples Bay, together with the Campania Plain, represents one of the most important Neogene-Quaternary basins of the peri-Tyrrhenian area. It is located in a sector linking the southern Apennines and the Tyrrhenian Sea, whose tectonic setting is strictly related with the geodynamic evolution of the back-arc basin-Apenninic chain-foredeep system during late Neogene and Quaternary times. The extensional processes in the Tyrrhenian area were contemporaneously active with compressional tectonic phases, leading to the individuation of the Apenninic chain and to the migration of the foredeep-chain system towards the Apulian foreland (MALINVERno \& RYAN, 1986; Oldow et alii, 1993; Ferranti et alii, 1996; Casciello et alii, 2006; Patacca \& Scandone, 2007). Previous studies have evidenced that the peri-Tyrrhenian area, in particular along the Campania-Latium continental margin, is characterized by the occurrence of sedimentary basins, perpendicular to the Apenninic chain, individuated in correspondence to transfer vertical faults, having a NESW (counter-Apenninic) trending (BARTOLE et alii, 1983; 


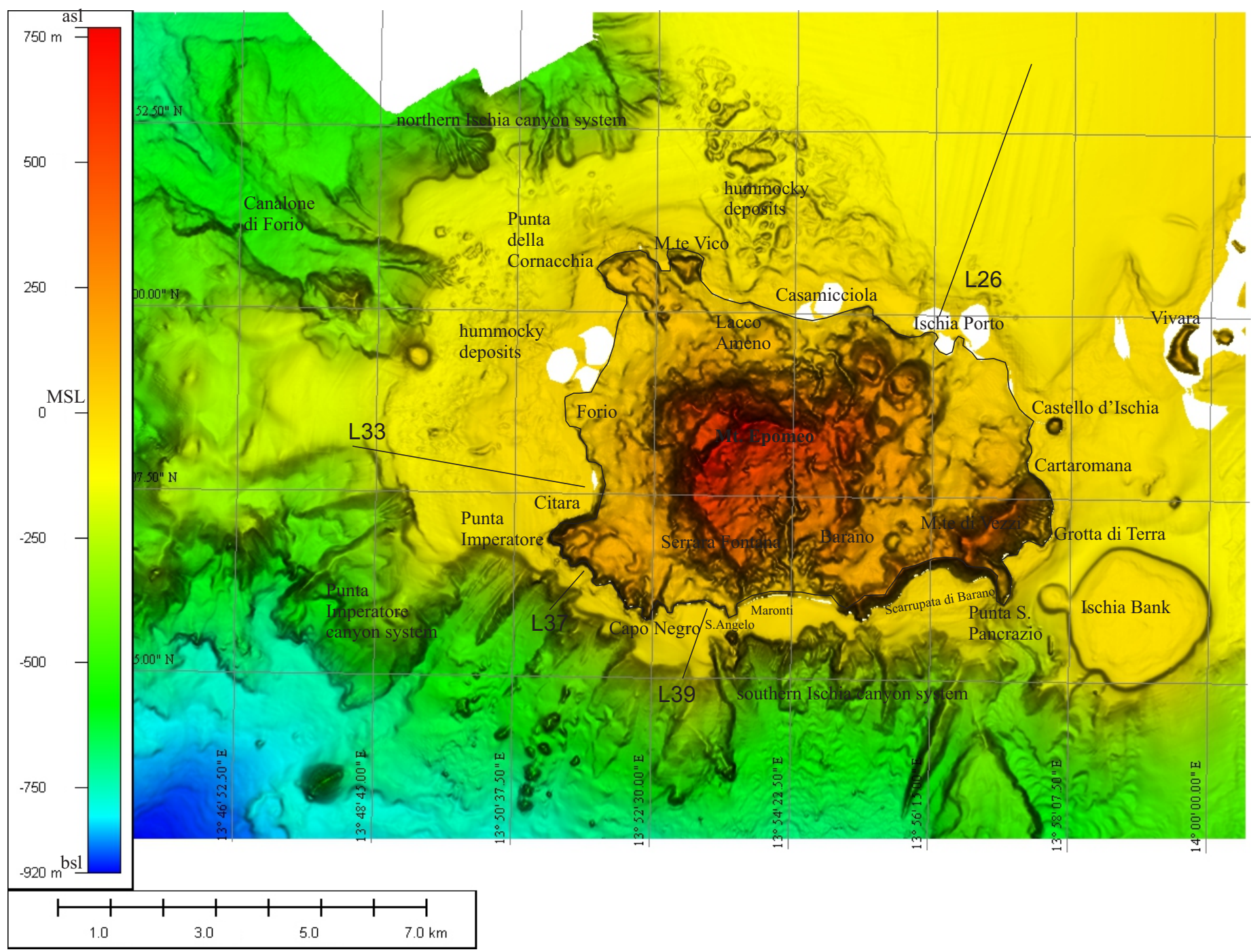

Fig. 3 - Digital Elevation Model (DEM) with superimposed seismic lines. The onshore-offshore DEM of Ischia Island is reported from AIELLo et alii (2009). Elevation and depth are in meters asl and bsl, respectively. Geographic coordinates are expressed in degrees. MSL, mean sea level. White areas in the map indicate voids in the Multibeam data acquisition.

Mariani \& Prato, 1988; Sacchi et alii, 1994; Acocella et alii, 1999; Aiello et alii, 2000; Milia \& Torrente, 2003; Moeller et alii, 2013; Contr et alii, 2017).

Geologic and volcanologic studies have been carried out on Ischia island, starting from the geological synthesis of RitTMANN $(1930 ; 1948)$ and following with the punctual aspects of the eruptive activity of the island and related geological processes (Ducci et alii, 1967; ForcelLa et alii, 1981; Gillot et alii, 1982; Chiesa et alii, 1985; 1987; Poli et alii, 1987; 1989; CRISCI et alii, 1989; CIVETTA et alii, 1991; Orsi et alii, 1991; 1996; LuONGo et alii, 1997; De ViTA et alii, 2006; Brown et alii, 2008; Della Seta et alii, 2012).

Ischia Island represents an alkali-trachytic volcanic complex, whose eruptive activity lasted from the Late Pleistocene up to historical times (Vezzoli, 1988). The oldest rocks date back to about $150 \mathrm{ky}$ and crop out in several sectors of the coastal belt of the island, mainly in correspondence to the "Scarrupata di Barano", a steep slope located in the south-eastern sector of the island. This evidence has suggested the occurrence of a resurgent caldera, about $10 \mathrm{~km}$ wide, where the eruptive activity coupled with the tectonic activity gave rise to the uplift along faults of the Mount Epomeo block (Orsi et alii, 1991). Five eruptive cycles have been identified by the succession of the eruptive events, ranging in age from $135 \mathrm{ky}$ to prehistorical and historical times. Moreover, the extensional tectonics related to the tectonic uplift of the Mt. Epomeo block has been interpreted as intra-calderic resurgence (AcocelLA \& FuNICIELLO, 1999) and genetically related to shallow seismicity, triggering gravity instabilities on the Mt. Epomeo relief. Significant geophysical studies on Ischia Island have been recently provided based on the geological interpretation of Sparker data within marine geological projects (AIELLO et alii, 2012; Aiello \& Marsella, 2014; 2015a; 2015b). High resolution seismic reflection profiles (Sparker Multitip; CorRadi et alii, 2009; GIORDANo et alii, 2013; AIELlo et alii, 2016) have been presented (BIAGIO, 2007; SBRANA et alii, 2011; Aiello et alii, 2012; Aiello \& Marsella, 2014; 2015a; $2015 b)$. New geological data have been provided pertaining the slide deposits and the canyon systems in the Is- 
land of Ischia offshore based on detailed seismo-stratigraphic interpretation in order to improve the knowledge on its geologic evolution during the Quaternary (AIELlo \& MarSELla, 2014; 2015b).

Several geomorphologic hints including uplifted marine terraces and beach rocks (CINQue et alii, 1997) have testified phenomena of subsidence and uplift in different sectors of Ischia Island. These phenomena caused a whole uplift of the Mt. Epomeo block of about $700 \mathrm{~m}$ during phases older and younger than the emplacement of the Epomeo Green Tuffs, happened at 55 ky (VEzzoli, 1988). The uplift of the Mt. Epomeo block has been dated back to 33 ky (GILLOT et alii, 1982).

The Ischia Island offshore is characterized by several monogenetic edifices aligned along a NW-SE trending fault system, connecting the south-eastern sector of Ischia to the Procida Island and to the Phlegrean Fields (Passaro et alii, 2016). The volcanic edifices have been formed through underwater explosive eruptions, documented by hyaloclastites coming from a potassic magma of latite-basaltic and latitic composition (Di GIRolamo et alii, 1984). Geophysical data have shown the occurrence of collapsed volcanic edifices located to the west and to the south-west of the Ischia Island, a sector of the sea bottom characterized by a strong residual magnetic anomaly field (BRUNO et alii, 2002).

The geologic and volcanologic history of the island was controlled by a main event, represented by the eruption of the Epomeo Green Tuffs, about $55 \mathrm{ky}$, allowing for the down throwing of the central part of the island. After the formation of the caldera of the Epomeo Green Tuffs the volcanic activity of the island was conditioned by the caldera resurgence, starting from $30 \mathrm{ky}$, which allowed for a gradual uplift and emersion of the rocks deposited in the caldera itself, which were submerged below the sea level. The rate of uplift, indicating the caldera resurgence, has been evaluated in the order of 800-1100 m (BARRA et alii, 1992).

The Ischia graben is located in the central part of the island, representing a depression triangular in shape, located between Casamicciola, Barano and Ischia Ponte (Fig. 1) and bounded southwards by a system of normal faults (RITTMANN, 1930; Forcella et alii, 1981; Vezzoli, 1988; MatTERA, 1995). It is divided into two sectors by a NE-SW (counter-Apenninic) trending normal fault following the valley of Rio Corbore. Several faults and fractures round the Mt. Epomeo structure (Acocella et alii, 1997; Acocella \& Funiciello, 1999) with NE-SW (counter-Apenninic) directions.

Ischia Island is dominated by the Mt. Epomeo structure, resulting from a prominent resurgence, mainly if compared with the relatively small size of the calderas. The uplift has been accompanied from the reactivation of faults, seismic activity and renewal of volcanism. It may be considered as a main factor for inducing slope instability (De Vita et alii, 2006; Della Seta et alii, 2012).

\section{MATERIALS AND METHODS}

The seismic grid offshore Ischia was recorded using a Sparker Multitip seismic source. The marine data acquisition was realized during the technical activities for the realization of the geological map n. 464 Isola d'Ischia at the 1:25,000 scale (SBRANa et alii, 2011) down to the $200 \mathrm{~m}$ isobath. The seismic lines were plotted on the marine DEM of the Ischia Island in order to perform a detailed correla- tion between geological structures outcropping along the sea bottom and their morpho-bathymetric setting (Fig. 3).

The seismic grid interpreted in this paper is made of four seismic lines (Fig. 3). The seismic sections were recorded using a multi-electrode Sparker system (SAM96 Sparker; CoRRADI et alii, 2009; GIORDANO et alii, 2013; AIELLO et alii, 2016). This seismic source shows short pulse lengths for an equivalent energy discharge, coupled with an increase in peak pressure, representing the amplitude of the outgoing acoustic wave. The vertical resolution of the seismic data was about $1 \mathrm{~m}$. Sparker seismic lines have facilitated the stratigraphic correlations between the seismic sections and have revealed the differences in structural and stratigraphic setting between the seismic lines.

Selected seismic sections, one for each sector of the islands will be discussed. In this interpretation the correlation with the onshore geology has been taken into account in order to improve the geological results obtained through the geological interpretation of the seismic sections.

\section{RESULTS}

In the Ischia offshore a geologic interpretation of seismic profiles has been carried out aimed at constraining the distribution and the meaning of the sedimentary and volcanic seismic units recognized offshore the volcanic complex through seismic interpretation and at improving a detailed geologic knowledge of selected sectors of the island based on seismic stratigraphy.

Four correlations have been constructed and discussed for significant sectors of Ischia island (Figs. 1-3). A tentative stratigraphic correlation has been carried out based on the Ischia geological map (SBRANA et alii, 2011) and on the Ischia geosites (MonTI, 2011). The seismic data and geological interpretations herein presented show an integration and completion of previously-interpreted seismic lines of Ischia (AIEllo et alii, 2012; Aiello \& Marsella 2014; 2015b), from which are different and located in other sectors, which have not been previously studied in detail based on seismo-stratigraphic data integrated with the coastal morphology of the island.

In the southern Ischia sector the geological interpretation of the L39 seismic line has been carried out and correlated onshore with the stratigraphy of pyroclastic deposits cropping out in the Succhivo coastal cliff. In the northern offshore of the island the geological interpretation of the L26 Sparker line has been performed and correlated onshore with the low sandy coast of Ischia Porto ("Spiaggia degli Inglesi" beach). In the eastern Ischia offshore the geological interpretation of the Sparker line L55 has been carried out and correlated onshore with the low sandy coast of eastern Ischia next to the Carta Romana beach. In the south-western offshore of the island the geological interpretation of the Sparker seismic line L37 has been achieved and correlated with the volcanic successions cropping out onshore in the Punta dello Schiavo coastal cliff, pertaining to the Punta Imperatore physiographic domain.

\section{SPARKER LINE L39/SuCCHIVO COASTAL CLIFF}

The L39 seismic line is located in the southern Ischia offshore, having a NE-SW trending and crossing the Ischia 
(a)

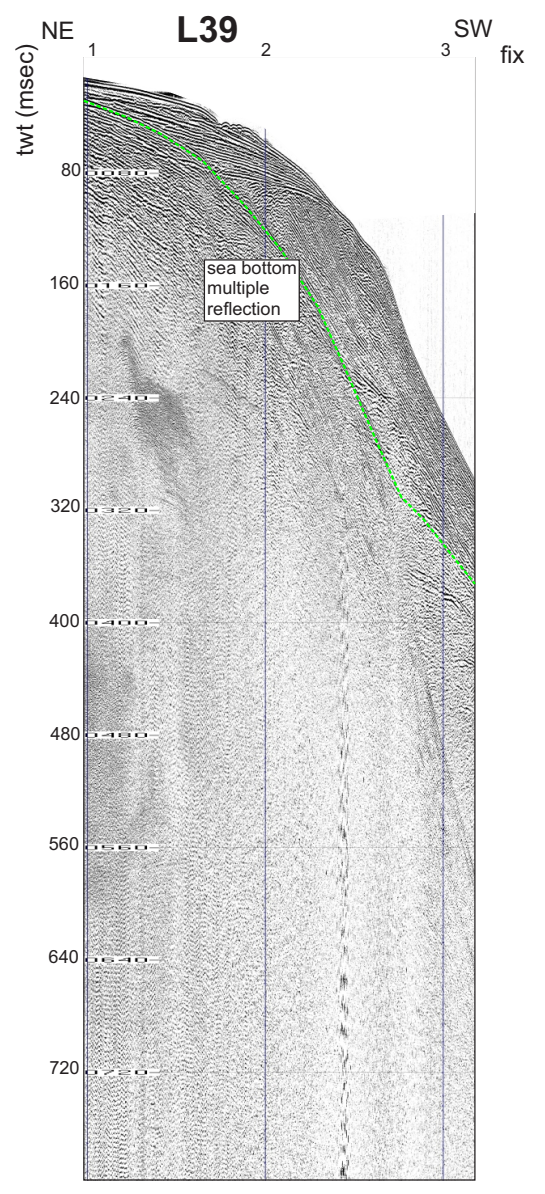

(b)

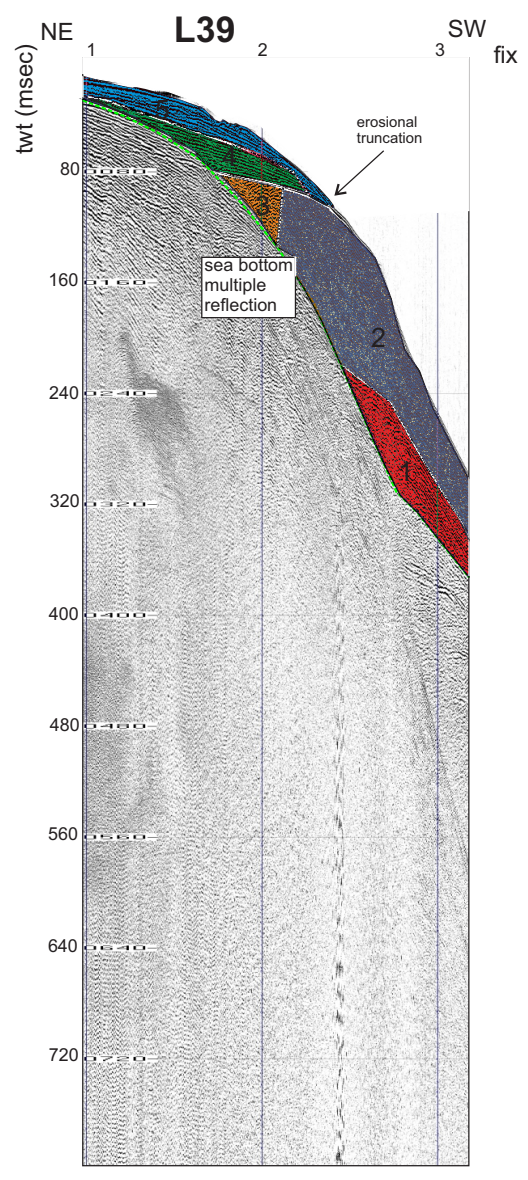

Fig. 4 - (a) Sparker line L39 located in the southern Ischia Island offshore from Succhivo towards the Tyrrhenian Sea; (b) geological interpretation of the Sparker line L39. Note the occurrence of five main seismic units, discussed in the text. Key: 1, Undifferentiated volcanic acoustic basement; 2 , Marine slope deposits; 3, Undifferentiated pyroclastic unit; 4, Transgressive System Tract (TST), late Quaternary depositional sequence; 5 , Highstand System Tract (HST), Late Quaternary depositional sequence. coastal belt offshore the Succhivo coastal cliff towards the Tyrrhenian Sea (Fig. 4a, b). A strong sea bottom multiple reflection, reported as a thin green dotted line in Fig. 4a, has prevented for the geological interpretation below its depth. Five main seismic units have been distinguished on this seismic line based on the geological interpretation (Fig. 4b). The first seismic unit (1 in Fig. 4b) is characterized by discontinuous seismic reflectors, detected in the deepest part of the seismic line. It has been interpreted as an undifferentiated volcanic acoustic basement. The unit 1 is overlain by a thick marine seismic unit ( 2 in Fig. 4b), characterized by continuous and oblique seismic reflectors, deposited in slope settings and widely cropping out at the sea bottom in the upper slope (Fig. 4b). The unit 2 is laterally coeval with another seismic unit (3 in Fig. 4b), whose seismic facies characterized by discontinuous reflectors and outer shape as a palaeo-channel fill have suggested its interpretation as an undifferentiated pyroclastic seismic unit (Fig. 4b). Both the seismic units 2 and 3 are truncated upwards by an erosional unconformity, directly overlain by the deposits of the seismic units 4 and 5 . Based on the retrogradational (unit 4) and aggradational (unit 5) stacking patterns these deposits have been respectively interpreted as the Transgressive System Tract (TST) and the Highstand System Tract (HST) of the late Quaternary Depositional Sequence (Fig. 4b).

The Succhivo tuff coastal cliff, located in correspondence to the coastal belt of southern Ischia Island, adjacent to the L39 seismic line, previously discussed and the corresponding stratigraphy inferred from geological maps of the Island of Ischia (SBrana et alii, 2011) are discussed below and reported in Fig. 5.

\section{SGL (Sant'Angelo Tuffs)}

Succession of hydromagmatic tuffs from a tuff cone located in the offshore of Punta del Chiarito. From the bottom of the tuff coastal cliff sequence plurimetric, poorly lithified, massive, lithic rich, tuff breccias. The matrix is formed by pumiceous lapilli, bombs and ashes. Proceeding upwards in the succession stratified dune-bedded gray yellow tuffs, rich in impact sags attributable to pyroclastic surges. The pyroclastic sequence is closed by plane parallel bedded, gray, coarse-grained and fine-grained ash tuffs, rich in accretionary lapilli beds, mainly formed by fall-out deposits. The tuff cone has been partially buried by marine sediments of the Sant'Angelo Bay has been identified by subaqueous geological survey and by marine geological data (SBRANA et alii, 2011).

Age K/Ar 19-20,6 ky +/- 1,2 (Poli et alii, 1987).

\section{fbc (coastal cliff toe deposits)}

The fbc unit is mainly composed of blocks. It is represented by clast-supported deposits formed by heterometric, decimetric to metric sized, lava and tuff blocks, sometimes with gravelly-sandy matrix. The deposits have a chaotic structure. Their age ranges between the Upper Holocene and the current. 


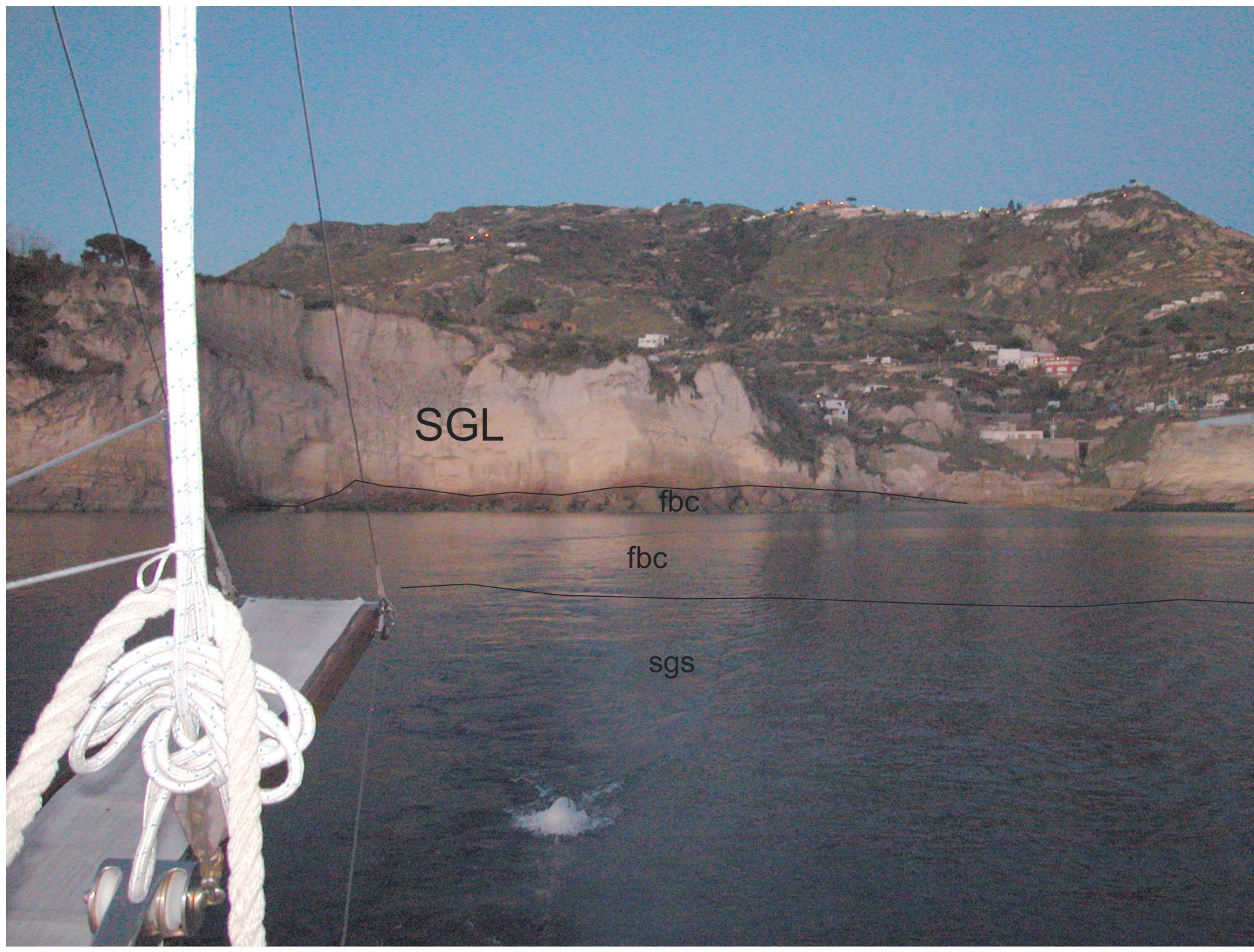

Fig. 5 - The Succhivo tuff coastal cliff. A sketch geological interpretation of the corresponding units is reported based on the geological map of Ischia Island (SBRANA et alii, 2011). The outcropping sequence is represented by the Sant'Angelo Tuffs (SGL). The sea cliff deposits (fbc) have also been reported in their emerged part and they are supposed to continue below the sea bottom, grading to the submerged beach deposits (sgs).

\section{sgs (submerged beach deposits)}

The sgs unit is mainly composed of gravels and sands. It is distinguished from moderately rounded to rounded clast-supported gravels, sandy gravels and coarse-grained sands with pyroclastic and lava pebbles with medium-tofine-grained sandy matrix deposits. Their age ranges between the upper Holocene and the current.

\section{SparkeR LiNe L26/SpiagGia DEgli IngLesi/Ischia Harbor}

The L26 Sparker profile, SSW-NNE trending crosses the offshore of Ischia harbor towards the Tyrrhenian offshore northwards of the island (Fig. 6a, b). A strong multiple reflection, relative to the sea bottom has inhibited the seismic interpretation below $230 \mathrm{msec}$ (twt; Fig. 6a, b). The geological interpretation of the seismic section has evidenced the occurrence of six seismic units, both volcanic and sedimentary in origin (Fig. 6a, b). An undetermined volcanic acoustic basement has been interpreted, characterized by an acoustically-transparent seismic facies with scattered and discontinuous seismic reflectors. The volcanic acoustic basement is bounded upwards by a continuous seismic reflector. This reflector represents also the base of the overlying seismic unit, which is probably constituted of marine deposits. This seismic unit is characterized by continuous and sub-parallel seismic reflectors and is the first unit of the basin filling ( 1 in Fig. 6b). The second and the third seismic units have similar seismic characteristics and a similar geologic interpretation may be inferred (2 and 3 in Fig. 6b). The fourth seismic unit of the basin filling directly crops out at the sea bottom and is established from highly continuous and parallel seismic reflectors, interpreted as recent marine sediments (Fig. 6b). The hummocky deposits have been considered to be as two distinct and superimposed bodies, characterized by discontinuous to chaotic seismic reflectors (H1 and H2 in Fig. 6b).

The occurrence of two different wedges has suggested that two distinct volcano-tectonic events have probably controlled the emplacement of the Ischia harbor slide deposits, genetically related with similar deposits located in the Casamicciola offshore (DE AlteriIs \& Violante, 2009; 
(a)

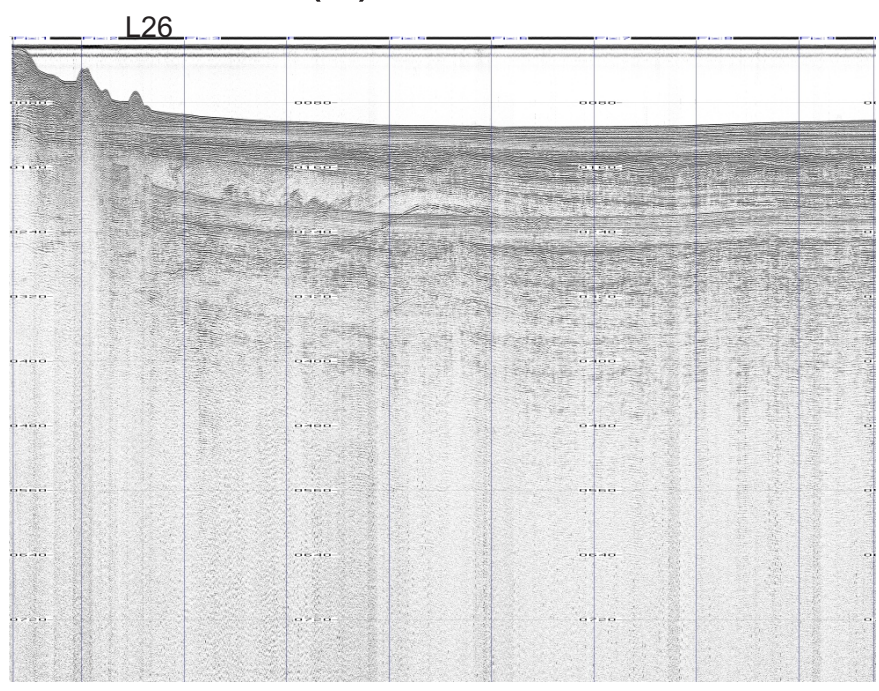

(b)

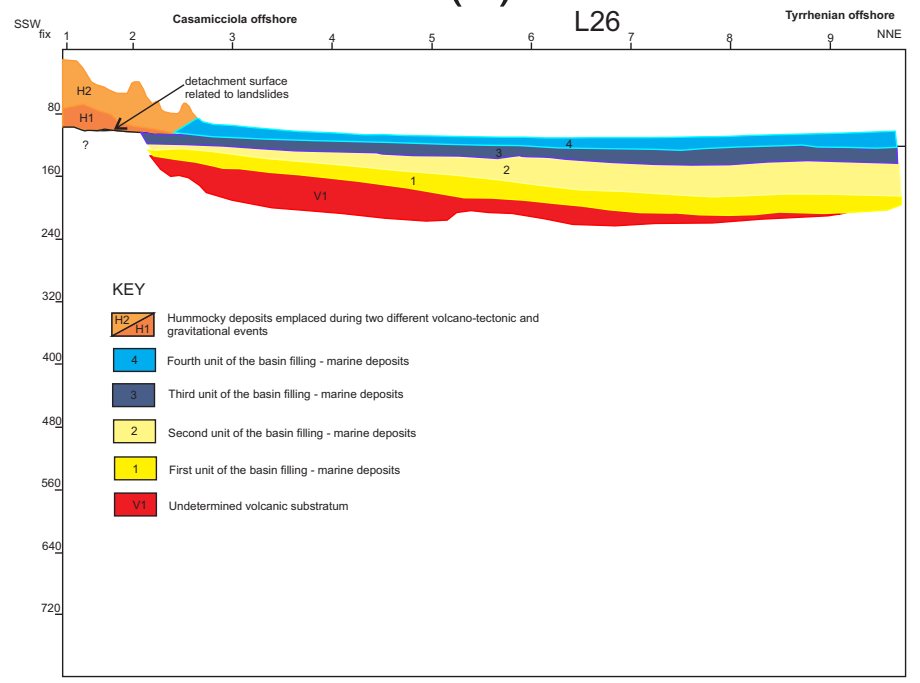

Fig. 6 - (a) Sparker line L26 from the Ischia Island harbor towards the northern offshore; (b) geological interpretation of the seismic line L26 (see the text for further details).

SBrana et alii, 2011; Aiello et alii, 2012). Moreover, previous seismo-stratigraphic data have evidenced that the incised fan-shaped valley developing in the Lacco Ameno offshore should be related with the emplacement of a recent landslide event. This event has left a channel-like scar and a genetically related depositional levee to the west (DE AlteriIs \& Violante, 2009).

Based on this interpretation the wedge named as $\mathrm{H} 2$ in seismic line L26 on the Island of Ischia harbor continental shelf may be related with a very recent landslide event, tooking place offshore Lacco Ameno and incised and modified previous deposits related to slides in the Ischia harborCasamicciola area (H1 in seismic line L27; AIELLO et alii, 2012), deeply modifying their topography in their western part. This interpretation is in overall agreement with the pathways of terrestrial landslides detected in the northern flank of the Mt. Epomeo block, whose pathways are directed towards Lacco Ameno and Casamicciola (Mele \& Del Prete, 1998; Del Prete \& Mele, 2006; De Vita \& alii, 2006; Della Seta \& alii, 2012; De Vita \& alii, 2013).

The coast of northern sector from the Ischia harbor to the Spiaggia degli Inglesi beach, adjacent to the seismic line L26 is discussed based on geological mapping and significant geosites of the island (MonTI, 2011; SBrana et alii, 2011). The harbor is located in a crater of a scoria cone formed after an explosive eruption, happened during historical times. The stratigraphy from the Ischia harbor towards the "Spiaggia degli Inglesi" is characterized by three main geological units on the Ischia Island geological map (SBRANa et alii, 2011). This tract of the shoreline is shown in Fig. 7, representing one significant geosite (MonTI, 2011).

\section{PIH- Ischia Porto spatter}

This unit crops out mainly in the surroundings of the volcanic crater of the harbor of Ischia Island. It is represented by black spatter and scoriaceous trachytic breccias forming the ramparts of the harbor crater. This crater has been deeply investigated by Buchner (1986), who has singled out the occurrence of a layer of reddish scoriae, probably emplaced during historical times (post V century B.C.).

\section{SNA - Sant' Alessandro pyroclastites and lavas - Foce Member}

This unit outcrops along the coastal cliff of Ischia harbor from Parata to Cafiero. It is represented by a lava flow, light grey in colour, strongly fractured and having a trachytic composition.

\section{ING - Spiaggia degli Inglesi spatter}

This unit outcrops along the coastal cliff adjacent to the "Spiaggia degli Inglesi" and is represented by dark grey lavas and spatters linked to a local small volcanic center, having a thickness of 15-20 m.

\section{Sparker line L33/Western Ischia Offshore/CAVa Dell'isola $\mathrm{BEACH}$}

The L33 seismic line crosses the western Ischia offshore from the basin to the continental shelf (Fig. 8a, b), having a ENE-WSW trending. The shelf break is located at water depths of $160 \mathrm{msec}$ (twt), corresponding to an average water depth of $136 \mathrm{~m}(1700 \mathrm{~m} / \mathrm{s})$.

Nine seismic units have been distinguished in the western Ischia offshore, volcanic, volcaniclastic and sedimentary in origin (Fig. 8b). The stratigraphic architecture of the continental shelf is characterized by two thick seismic sequences, having a seismic facies with discontinuous and chaotic seismic reflectors, superimposed one to each other through a sub-parallel unconformity. These two units, namely $\mathrm{H} 1$ and $\mathrm{H} 2$ have been interpreted as the hummocky deposits occurring in the western Ischia Island offshore during complex geologic and volcano-tectonic processes. The 




Fig. 7 - "Spiaggia degli Inglesi” beach (white arrow) at Ischia Island harbor (northern sector).

(a)

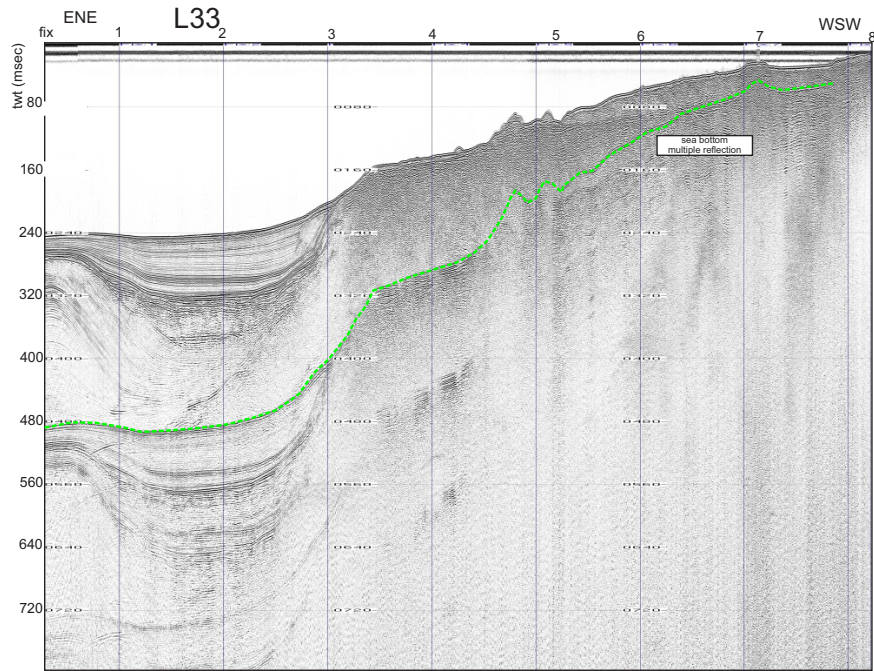

(b)

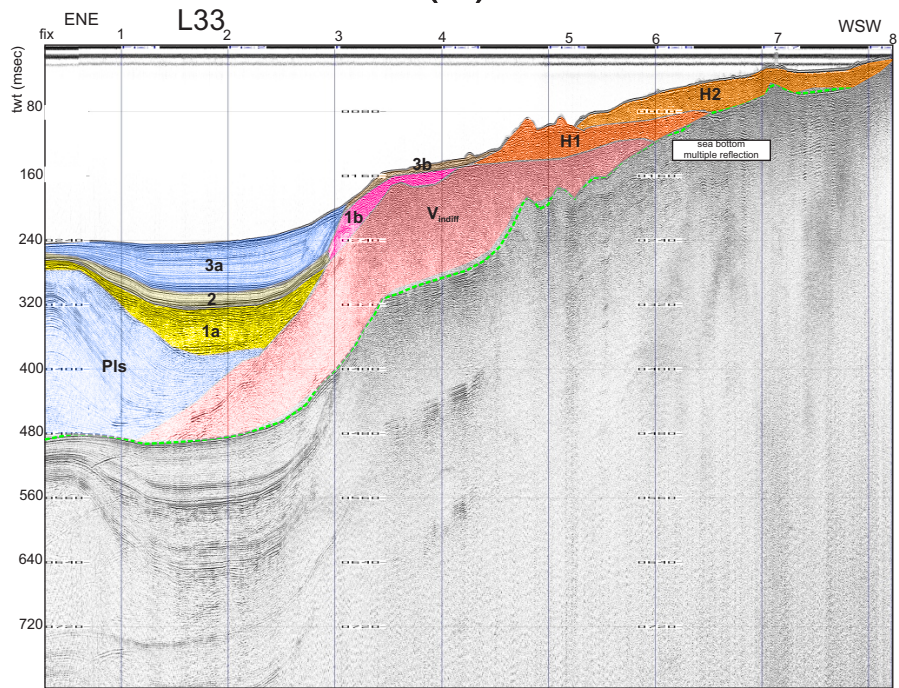

Fig. 8 - (a) Sparker line L33 located in the western Ischia Island offshore from Forio d'Ischia towards the Tyrrhenian Sea; (b) geologic interpretation of the seismic line L33. Note the occurrence of nine main seismic units, discussed in the text. Key: Vindiff, Undifferentiated volcanic acoustic basement, genetically related with the Citara tuffs; Pls, relict Pleistocene prograding wedge; 1a, first seismic unit of the basin filling in the western Ischia Island offshore; 1b, shelf margin wedge overlying the volcanic acoustic basement; 2 , second seismic unit of the basin filling in the western Ischia Island offshore; $3 a$, third seismic unit of the basin filling in the western Ischia Island offshore; 3b, shelf margin wedge, outcropping from the sea bottom; H1, hummocky deposits (phase 1); H2, hummocky deposits (phase 2). 
occurrence of two different seismic units, clearly documented through seismic interpretation and previously unknown suggests that the emplacement of the hummocky deposits in the western Ischia offshore happened during at least two different phases of submarine sliding. These seismic data are in overall agreement with the seismic data shown in the northern Ischia offshore, where two similar seismic sequences have been recognized and discussed (Fig. 6b).

The H1 seismic unit unconformably overlies a thick seismic unit, characterized by an acoustically-transparent seismic facies, which has been interpreted as undifferentiated acoustic basement, whose origin is probably volcanic ( $\mathrm{V}_{\text {indiff }}$ in Fig. 8b). This unit has been continuously detected from the shelf through the slope and towards the basin. It appears deeply eroded in correspondence with the continental slope, where it is directly overlain by the seismic unit $1 \mathrm{~b}$. This unit represents a shelf margin wedge, characterized by discontinuous seismic reflectors and is the correlative seismic unit of the seismic unit 1a (Fig. 8b). The seismic unit 1a is the first seismic unit of the basin filling, characterized by discontinuous seismic reflectors (Fig. 8b). In the basin the volcanic seismic unit, namely the $V_{\text {indiff }}$ seismic unit is laterally coeval with the Pls seismic unit, which is characterized by prograding and oblique seismic reflectors (Fig. 8b). The seismic facies of the Pls seismic unit suggests that it should represent a relict Pleistocene prograding wedge, similar to Pleistocene prograding wedges which characterize the stratigraphic architecture of the Naples continental shelf and slope from Early to Late Pleistocene times (D'ArgenIo et alii, 2004).

The basin filling of the western Ischia offshore is composed of three main seismic units (1a, 2a and 3a in Fig. 8b), the first of which has been already discussed. These units progressively onlap on the flanks of the volcanic seismic unit $\mathrm{V}_{\text {indiff }}$ and of the overlying seismic units $1 \mathrm{~b}$ and $3 \mathrm{~b}$, representing the correlative units of the $1 \mathrm{a}$ and $3 \mathrm{a}$ seismic units, respectively on the slope (1b) and in the shelf (3b). Their seismic facies is characterized by parallel seismic reflectors (Fig. 8b).

The coast of western Ischia southwards of the Forio town, in correspondence to the beach of Cava dell'Isola, adjacent to the seismic line L33 is herein discussed based on geological mapping and significant geosites of Ischia (MonTI, 2011; Sbrana et alii, 2011). The Forio debris avalanche, located in western Ischia, represents an important geosite of Ischia (MonTI, 2011). The deposits of the Forio debris avalanche crop out in the Forio d'Ischia town and in the surrounding areas. They are located towards valley with respect to the large slide scar of Falanga-Rione Bocca and along the coastal tract between the San Francesco Bay and Citara. The slide deposits have been partly reworked in marine environment, as suggested by the rounded blocks cropping out along the Forio-Citara littoral. Proceeding from the shoreline, in continuity with the onshore outcrops, the debris avalanche continues up to the sea bottoms up to a distance of 4-5 $\mathrm{km}$ from the coast, reaching water depths of about $150 \mathrm{~m}$.

From the San Francesco Bay to the Forio harbor the sea bottoms are characterized by middle-to-fine-grained sands. Near shore these deposits grade into gravels and pebbles with blocks of the Epomeo Green Tuffs, often prevalent (Monti, 2011; SBrana et alii, 2011).

The stratigraphy of the coastal cliff of western Ischia in correspondence with the "Spiaggia degli Inglesi" beach is characterized by two main geological units on the Ischia geological map (SBRANA et alii, 2011). These units have been recognized in the sketch interpreted photograph of Fig. 9, representing the study area.

\section{TCT - Citara Tuffs}

The Citara tuffs are represented by white to yellow ash tuffs and lapilli-rich ash tuffs. These deposits refer to the activity of tuff cones in the Citara offshore, as suggested by the sea floor morphology and by the onlap geometries of the subaerial unit at Punta Imperatore.

Age K/Ar 42-45 ky +/- 1,1 (Poli et alii, 1987).

\section{TPR - Punta delle Pietre Rosse tuffs}

The Punta delle Pietre Rosse tuffs are represented by massive, brown ash tuffs, which appear to be supported by matrix, including pumice clasts and characterized at their top by a thin paleosol.

The marine deposits detected in the surrounding coastal belt are represented by the present and recent beach deposits $\left(\mathrm{g}_{2}\right)$, grading seawards into the submerged beach deposits (sgs; SBRANA et alii, 2011).

\section{$g_{2}$ - present and recent beach deposits}

The beach deposits representing the Cava dell'Isola beach are composed of heterometric medium-coarse-tofine-grained sands with pebbles, locally enclosing rocks. Their age ranges between the Upper Holocene and the current.

\section{sgs - submerged beach deposits}

The submerged beach deposits are distinguished from rounded gravels, sandy gravels and coarse-grained sands, including pyroclastics and lava pebbles supported by a medium-to-fine-grained sandy matrix. Their age ranges between the Upper Holocene and the current.

\section{Sparker line L37/Punta Dello Schiavo coastal clifF}

The L37 seismic line is located in the south-western Ischia offshore in correspondence to the promontory of Punta dello Schiavo (Fig. 10a, b), having a SW-NE trending. The line has crossed a continental shelf-upper slope section up to water depths of about $500 \mathrm{msec}$ (twt), corresponding to an average water depth of about $425 \mathrm{~m} \mathrm{(1700}$ $\mathrm{m} / \mathrm{s}$ ). Six seismic sequences have been recognized in this seismic line based on geological interpretation (Fig. 10a, b). The prevalent sequence is characterized by an acoustically transparent seismic facies and by the occurrence of many diffraction hyperbola (Vindiff in Fig. 10b). This sequence is probably volcanic in origin and has been interpreted as an undifferentiated volcanic acoustic basement. On the continental shelf this sequence is directly overlain by an aggradational/progradational sequence, interpreted as the lowstand system tract (LST in Fig. 10b). The LST deposits, are, in turn, overlain by a retrogradational seismic sequence interpreted as the transgressive system 


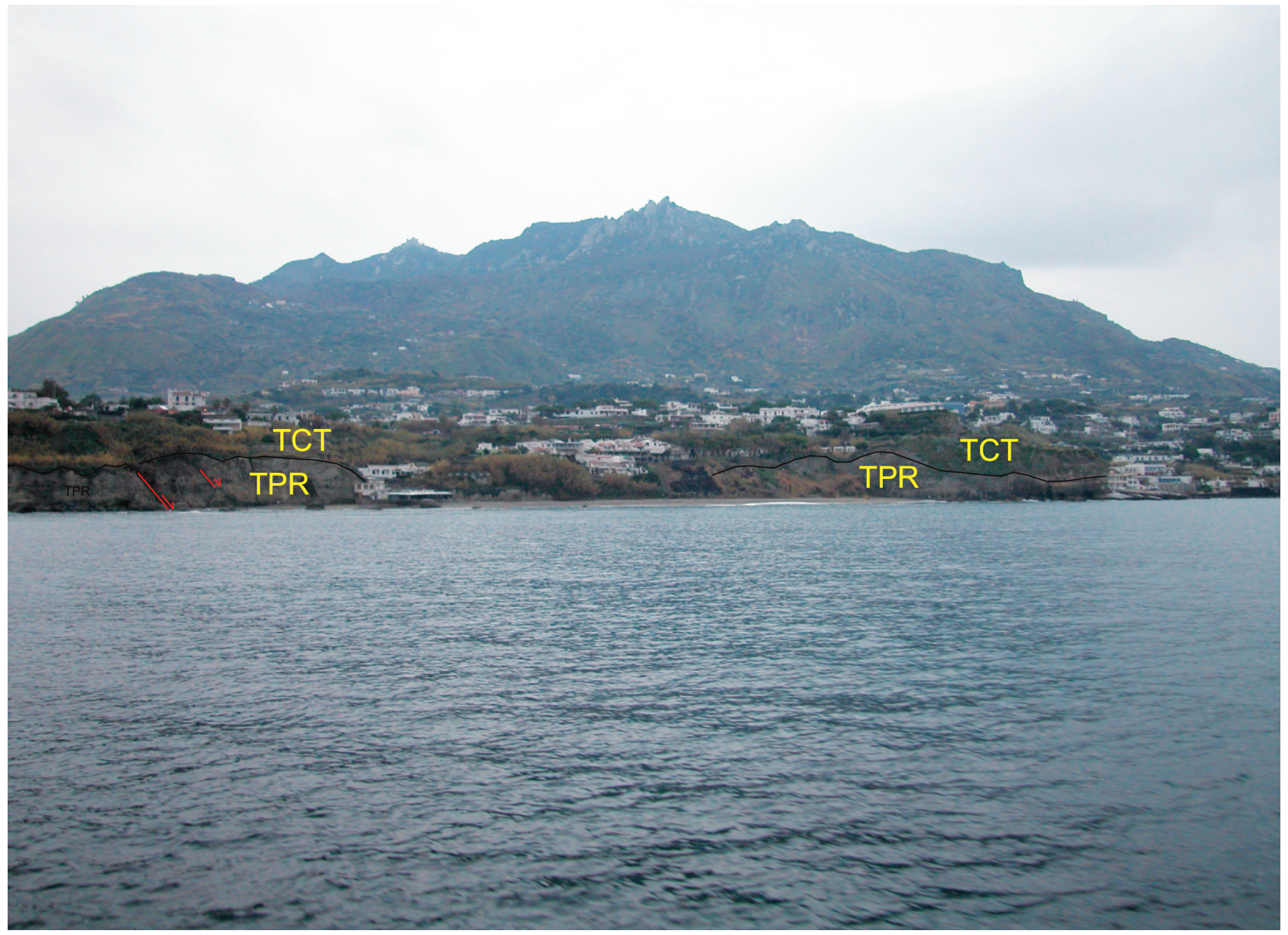

Fig. 9 - The coastal cliff of western Ischia Island in correspondence with the "Spiaggia degli Inglesi" beach: TPR, Punta delle Pietre Rosse tuffs; TCT, Citara tuffs.

tract (TST in Fig. 10b). The TST deposits are covered by an aggradational seismic sequence, cropping out at the sea bottom, interpreted as the highstand system tract (HST in Fig. 10b). All the three sequences form the late Quaternary depositional sequence, related with the last glacio-eustatic cycle and well recognized in the Naples Bay (Milia, 2000; Aiello et alii, 2001; D’Argenio et alii, 2004; Aiello \& MARSELLA, 2013).

Two slope sequences have been identified based on seismic interpretation (Sl1 and Sl2 in Fig. 10b). They are characterized by oblique seismic reflectors and correlate with Holocene slope sediments. The Sl1 sequence has been identified from the shelf break to water depths of about $230 \mathrm{msec}$ (twt), corresponding to an average water depth of $195 \mathrm{~m}(1700 \mathrm{~m} / \mathrm{s})$. The $\mathrm{Sl} 2$ sequence has been recognized from $195 \mathrm{~m}$ to the bottom of the seismic section, corresponding to about $425 \mathrm{~m}$ (Fig. 10b).

The Punta dello Schiavo promontory pertains to the physiographic domain of Punta Imperatore, where high coastal cliff are dominant since to Punta del Chiarito. An important terrace rim is singled out at the toe of the coastal cliffs based on the geological maps. High coastal cliffs occur between Punta Imperatore and Punta del Chiarito. The sea bottom topography is strongly conditioned from the articulated physiography of the emerged sector. The rocky promontories occurring along the emerged coast continue seawards with a sub-vertical trending up to a water depth ranging between 25 and $35 \mathrm{~m}$. The base of the submerged slope is aligned with the continental slope engraved by different canyon heads (Monti, 2011; Aiello \& Marsella, 2014). The rocky promontories alternate with bays characterized by the occurrence of heterometric detritic deposits, composed of products derived from the dismantling of the coastal cliff. Terraced morphologies have been singled out at water depths ranging between 3 and $10 \mathrm{~m}$.

The stratigraphy of the Punta dello Schiavo coastal cliff is characterized by an outcropping pyroclastic sub-sequence, namely the $\mathrm{SUN}_{\mathrm{b}}$ sub-sequence (SBRANA et alii, 2011), corresponding to a sub-sequence of the Scarrupo di Panza pyroclastics (Fig. 11).

\section{$S U N_{b}-$ Scarrupo di Panza pyroclastics}

The Scarrupo di Panza pyroclastic deposits - member B in SBRANa et alii (2011) are characterized by trachytic grey tuffs and form a tuff coastal cliff having a high gradient at Punta dello Schiavo (Fig. 11). 
(a)

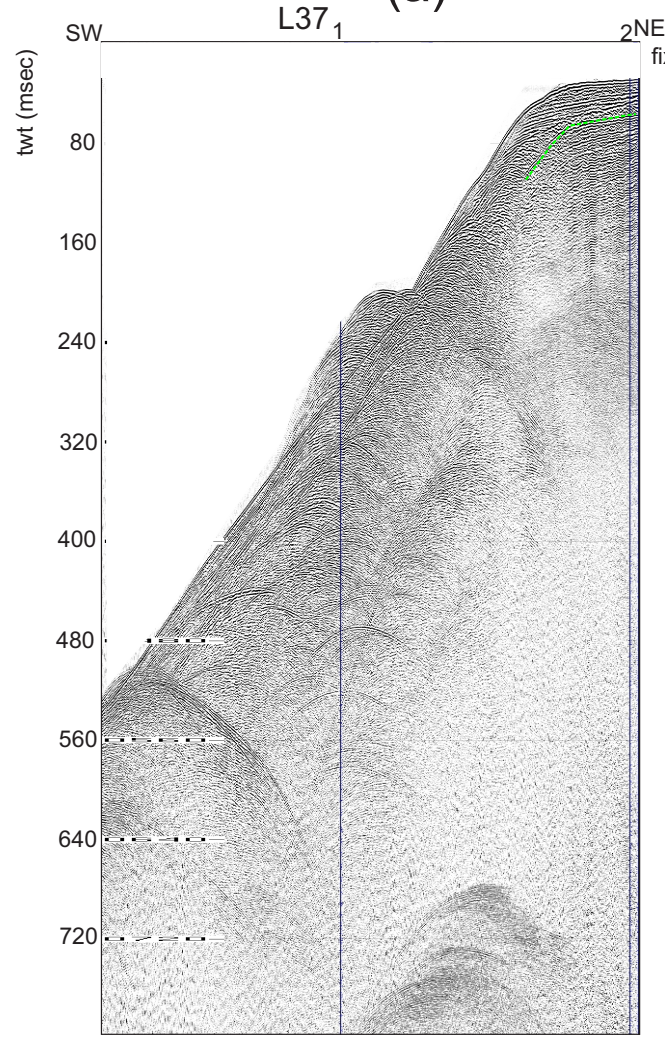

(b)

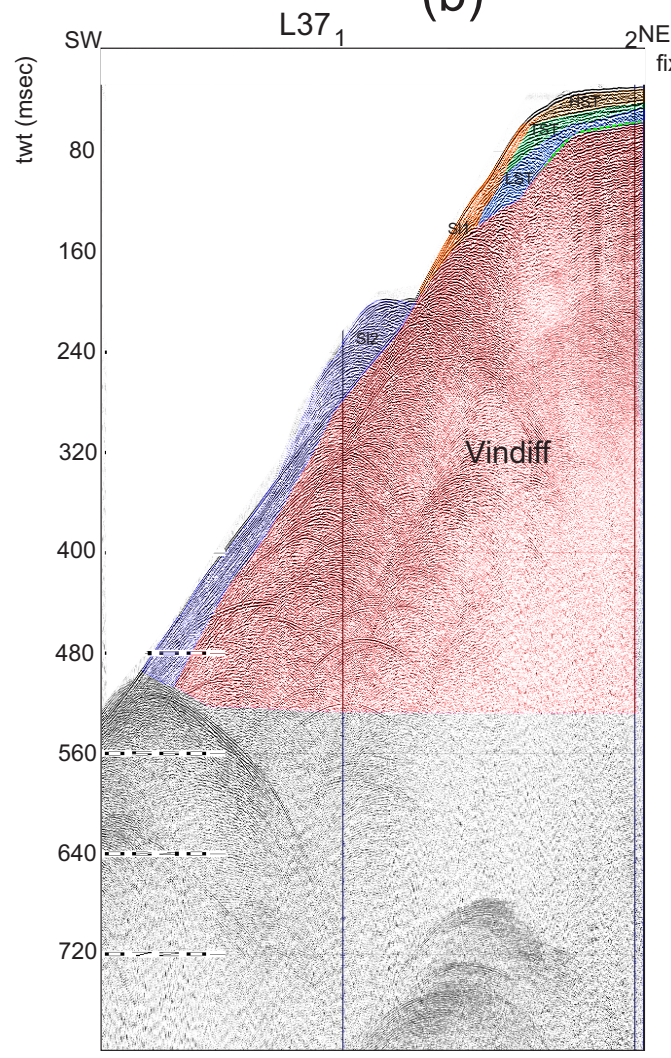

fix

Fig. 10 - (a) Sparker line L37 located in the south-western Ischia offshore from Panza towards the Tyrrhenian Sea; (b) geologic interpretation of the seismic line L37. Note the occurrence of six main seismic units, discussed in the text. Key: Vindiff, Undifferentiated volcanic acoustic basement, genetically related with the Scarrupo di Panza pyroclastic deposits; LST, lowstand system tract; TST, transgressive system tract; HST, highstand system tract; Sl1, Recent slope deposits (sequence 1); Sl2, Recent slope deposits (sequence 2).

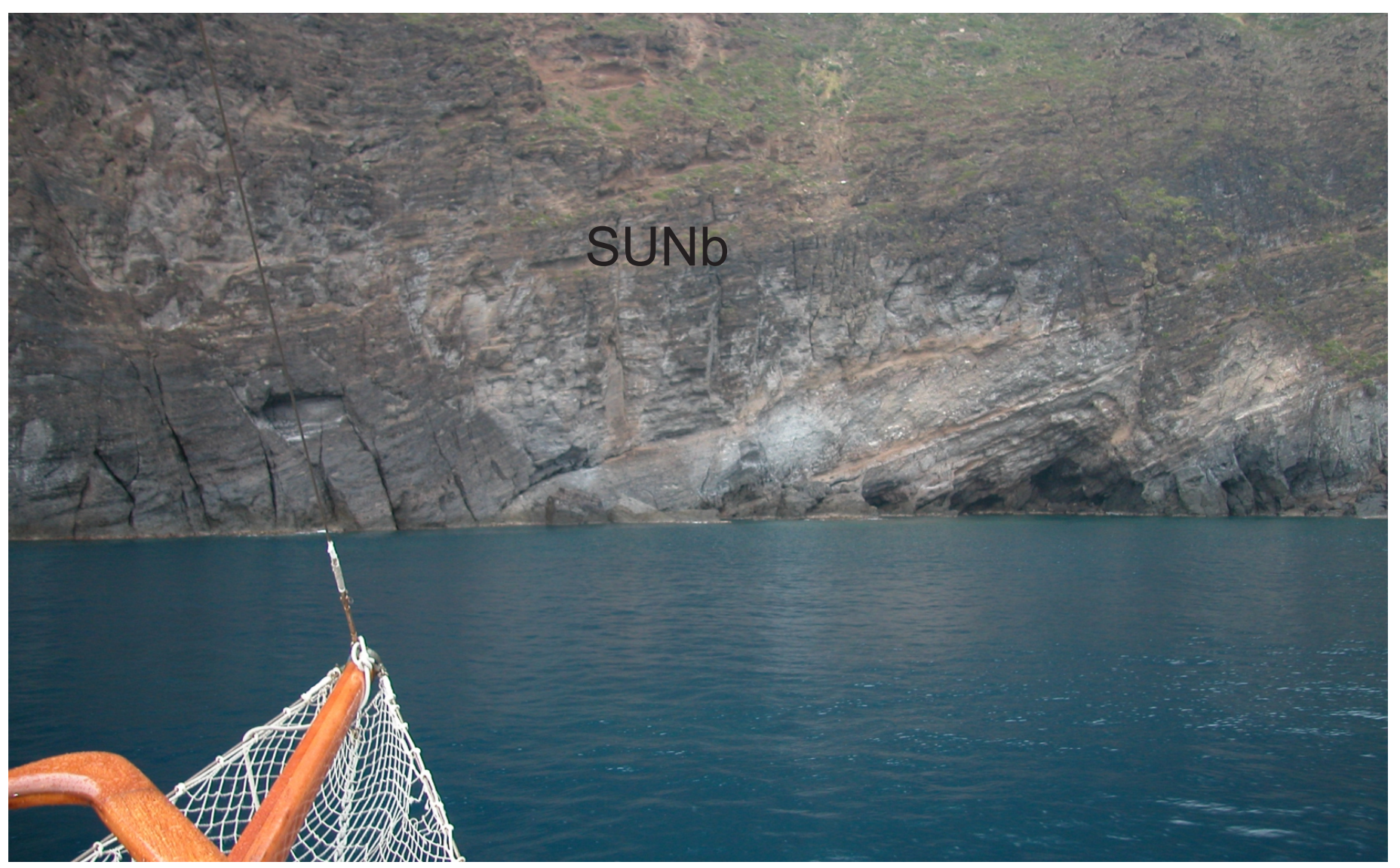

Fig. 11 - The Punta dello Schiavo coastal cliff (south-western Ischia): $\mathrm{SUN}_{\mathrm{b}}$, Scarrupo di Panza pyroclastic deposits. 
Based on geological maps the following units crop out at the sea bottom in the marine area surrounding Punta dello Schiavo.

$f b c$ - coastal cliff toe deposits - blocks

They are represented by clast-supported deposits formed by heterometric lava and tuff blocks with gravelly-sandy matrix. The deposits have a chaotic structure and sometimes they show a direct grading. The age ranges between Upper Holocene to present.

\section{pss - proximal inner shelf deposits - sands}

These deposits are composed of medium-to-finegrained sands and by litho-bioclastic sands with a pyroclastic pelitic matrix. Pyroclastic and lava pebbles are present and mollusk bioclasts. Their age ranges between the Holocene and the present.

\section{DISCUSSION}

A sketch table has been constructed in order to show the distribution of the seismic units in the studied sectors, reporting the location of the areas, the seismic units and the inferred stratigraphy onshore and offshore of the surrounding coastal belt based on geological maps (SBRANA et alii, 2011).

This table represents a useful base to discuss the distribution of the seismic units detected in the different sectors of the Island of Ischia. Five seismic units have been recognized in the Succhivo sector (southern Ischia), while six seismic units have been interpreted offshore the Ischia harbor. Nine seismic units occur offshore the Forio sector (western Ischia), while six seismic units have been detected in correspondence with the Panza sector (south-western Ischia).

The late Quaternary depositional sequence has been identified based on seismic interpretation as an incomplete sequence (TST + HST) in the Succhivo area, while it is well developed, as a complete sequence in the Panza area (LST+TST+HST). On the other side, it lacks both in the Ischia Island harbor area and in the Forio area (Table 1). This evidence suggests that the late Quaternary depositional sequence was well developed in the southern and south-western sectors of the island, while it lacks or it is very reduced in the northern and western sectors. This discussion improves the knowledge of the late Quaternary depositional sequences in the offshore. In this geological context, homogeneous data on the distribution of the late Quaternary depositional sequence in the Ischia offshore are still lacking and need to be further improved and discussed.

The highstand deposits of the Naples Bay have been intensively studied in the frame of research projects of marine geological mapping of the Campania Region (AIELLO et alii, 2001; D'ARgENIO et alii, 2004; SACCHI et alii, 2005; Insinga et alii, 2008; Molisso et alii, 2010). They have been widely documented in the Sarno prodelta system, about $40 \mathrm{~km}$ to the east of the island, where they are affected by an extensive creeping involving the post-79 AD succession (SACCHI et alii, 2005). Seismic data have suggested that gravitational instability of this area has been controlled by significant volcano-tectonic deformation and local uplift of the seafloor, pre-dating the eruptive event ( $\mathrm{S}_{\mathrm{ACCHI}}$ et alii, 2005).

In the Naples Bay the Transgressive System Tract (TST), deposited during the sea level rise (18-6 ky), consists of different stratigraphic units (Milia \& ToRRENTE, 2000; 2003). The most important is a thick progradational unit overlying the Neapolitan Yellow Tuff (15 ky; Deino et alii, 2004). In the Gulf of Pozzuoli, about $15 \mathrm{~km}$ to the northeast of Ischia Island, this progradational unit exhibits a lateral transition into a unit showing horizontal bedding. A series of volcanic edifices, two of them are the tuff cones of Nisida Bank and Nisida Island (SACCH et alii, 2009; AIELLO et alii, 2016) overlie the TST deposits in the eastern sector of the Pozzuoli Gulf.

In the Naples Bay the lowstand deposits have been however recognized on the margins of the Phlegrean banks (Miseno, Nisida and Pentapalummo) of the Gulf of Pozzuoli. Thick regressive prograding deposits have been recognized based on seismic interpretation on the south-eastern flank of the Pentapalummo Bank (SACCHI et alii, 2009; Airllo et alii, 2016).

The volcanic acoustic basements have been recognized based on the seismic interpretation in the Ischia offshore (Succhivo, Ischia harbor, Forio, Panza), identifiable on seismic sections as thick acoustically transparent seismic units (Figs. 4-10). Due to their uncertain genetic attribution they have been considered as undifferentiated volcanic acoustic basements $\left(\mathrm{V}_{\text {indiff }}\right.$ in the interpreted seismic sections and in the Table 1). Nonetheless this, the coastal stratigraphy based on Ischia Island geologic maps (SBRANA et alii, 2011; Table 1) has allowed to carry out a qualitative correlation of these volcanic units with volcanic and/ or pyroclastic units detected in the surrounding coastal sectors of Ischia Island. In particular, the volcanic acoustic basement recognized in the Succhivo area should be genetically related with the Sant'Angelo Tuffs, represented by hydromagmatic tuffs erupted from a tuff cone located in the Punta del Chiarito offshore. The volcanic acoustic basement recognized at the Ischia harbor should be genetically related with the Ischia Porto spatter, composed of scoriaceous trachytic breccias. The volcanic acoustic basement recognized in the Forio d'Ischia sector should be genetically related with the Citara tuffs, constituted by ash tuffs and lapilli-rich ash tuffs. Finally, the volcanic acoustic basement recognized offshore Panza (Punta dello Schiavo) should be genetically related with the Scarrupo di Panza pyroclastic deposits, composed of trachytic grey tuffs.

Significant hummocky deposits (H1 and $\mathrm{H} 2$ in the interpreted seismic sections and in the Table 1) have been identified both in the Ischia Island harbor and in the Forio d'Ischia offshore. Their distribution suggests that at least two phases of important submarine sliding may be suggested in the north-western Ischia offshore based on seismic data. The hummocky topographies are characterized by discontinuous to chaotic seismic reflectors. While these deposits crop out at the sea bottom in the Ischia Island harbor, in the Forio area they are covered by shelf margin wedges (unit $3 b$ in Table 1). The two seismic units interpreted as hummocky deposits appear to be separated by a well individuated parallel reflector, probably representing a detachment surface separating two main phases of emplacement of these deposits. 
TABLE 1

Offshore seismic stratigraphy, geologic interpretation and coastal stratigraphy.

\begin{tabular}{|c|c|c|c|c|c|}
\hline Location & $\begin{array}{c}\text { Coastal } \\
\text { morphology }\end{array}$ & $\begin{array}{l}\text { Seismic } \\
\text { units }\end{array}$ & Seismic facies & Geologic interpretation & $\begin{array}{l}\text { Coastal stratigraphy } \\
\text { (SBRANA et alii 2011) }\end{array}$ \\
\hline $\begin{array}{l}\text { Succhivo } \\
\text { (southern } \\
\text { Ischia) }\end{array}$ & $\begin{array}{l}\text { Succhivo } \\
\text { tuff coastal } \\
\text { cliff }\end{array}$ & $\begin{array}{l}\text { Five seismic } \\
\text { units } \\
(1,2,3,4,5)\end{array}$ & $\begin{array}{l}\text { 1: discontinuous seismic re- } \\
\text { flectors. } \\
\text { 2: continuous and oblique } \\
\text { seismic reflectors. } \\
\text { 3: discontinuous seismic re- } \\
\text { flectors. } \\
\text { 4: Continuous retrograda- } \\
\text { tional seismic reflectors. } \\
\text { 5: Continuous aggradational } \\
\text { seismic reflectors. }\end{array}$ & $\begin{array}{l}\text { 1: Undifferentiated volcanic } \\
\text { acoustic basement,genetical- } \\
\text { ly related with the S. Angelo } \\
\text { tuffs. } \\
\text { 2: Slope deposits, probably } \\
\text { Holocene in age. } \\
\text { 3: Undifferentiated pyro- } \\
\text { clastic deposits filling pal- } \\
\text { aeo-channels. } \\
\text { 4: Transgressive System Tract } \\
\text { (TST; late Quaternary deposi- } \\
\text { tional sequence. } \\
\text { 5: Highstand System Tract } \\
\text { (HST; late Quaternary depo- } \\
\text { sitional sequence. }\end{array}$ & $\begin{array}{l}\text { SGL Sant'Angelo tuffs. Hy- } \\
\text { dromagmatic tuffs erupted } \\
\text { from a tuff cone located in } \\
\text { the Punta del Chiarito off- } \\
\text { shore. } \\
\text { fbc coastal cliff toe deposits. } \\
\text { Lava and tuff blocks, some- } \\
\text { times with gravelly-sandy } \\
\text { matrix. } \\
\text { sgs submerged beach depos- } \\
\text { its: gravels and sands. }\end{array}$ \\
\hline $\begin{array}{l}\text { Ischia harbor } \\
\text { (northern } \\
\text { Ischia) }\end{array}$ & $\begin{array}{c}\text { Spiaggia } \\
\text { degli Inglesi } \\
\text { (sandy beach) }\end{array}$ & $\begin{array}{c}\text { Six seismic } \\
\text { units } \\
(\mathrm{V} 1,1,2,3,4 \\
\mathrm{H} 1, \mathrm{H} 2)\end{array}$ & $\begin{array}{l}\text { V1: acoustically-transparent } \\
\text { seismic facies with scattered } \\
\text { and discontinuous seismic } \\
\text { reflectors. } \\
\text { 1: continuous and sub-paral- } \\
\text { lel seismic reflectors. } \\
\text { 2: continuous and sub-paral- } \\
\text { lel seismic reflectors. } \\
\text { 3: continuous and sub-paral- } \\
\text { lel seismic reflectors. } \\
\text { 4: highly continuous and par- } \\
\text { allel seismic reflectors. } \\
\text { H1: discontinuos to chaotic } \\
\text { seismic reflectors. } \\
\text { H2: discontinuous to chaotic } \\
\text { seismic reflectors. }\end{array}$ & $\begin{array}{l}\text { V1: undetermined volcanic } \\
\text { acoustic basement, geneti- } \\
\text { cally related with the Ischia } \\
\text { Porto spatter. } \\
\text { 1: first unit of the basin fill- } \\
\text { ing. } \\
\text { 2: second unit of the basin } \\
\text { filling. } \\
\text { 3: third unit of the basin fill- } \\
\text { ing. } \\
\text { 4: recent marine sediments. } \\
\text { H1: hummocky deposits em- } \\
\text { placed during a first volca- } \\
\text { no-tectonic phase. } \\
\text { H2: hummocky deposits em- } \\
\text { placed during a second volca- } \\
\text { no-tectonic phase. }\end{array}$ & $\begin{array}{l}\text { PIH Ischia Porto spatter:sco- } \\
\text { riaceous trachytic breccias. } \\
\text { SNA } \\
\text { Sant'Alessandro pyroclastites } \\
\text { and lavas - Foce Member } \\
\text { Lava flow having a trachytic } \\
\text { composition. } \\
\text { ING Spiaggia degli Inglesi } \\
\text { spatter. Lavas and spatters. }\end{array}$ \\
\hline $\begin{array}{l}\text { Forio d'Ischia } \\
\text { (western } \\
\text { Ischia) }\end{array}$ & $\begin{array}{c}\text { Cava } \\
\text { dell'Isola } \\
\text { beach } \\
\text { (sandy beach) }\end{array}$ & $\begin{array}{c}\text { Nine seismic } \\
\text { units (Vindiff, } \\
\text { Pls, 1a, 1b, 2, } \\
\text { 3a, 3b, H1, } \\
\text { H2) }\end{array}$ & $\begin{array}{l}\text { Vindiff: acoustically trans- } \\
\text { parent seismic facies. } \\
\text { Pls: prograding and oblique } \\
\text { seismic reflectors. } \\
\text { 1a: discontinuous seismic } \\
\text { reflectors, correlative seismic } \\
\text { unit with respect to the seis- } \\
\text { mic unit } 1 \text { b. } \\
\text { 1b:discontinuous seismic re- } \\
\text { flectors; correlative seismic } \\
\text { unit with respect to the seis- } \\
\text { mic unit 1a. } \\
\text { 2:parallel seismic reflectors, } \\
\text { onlap on the flanks of the vol- } \\
\text { canic seismic unit } V_{\text {indiff }} \\
\text { 3a:parallel seismic reflectors; } \\
\text { correlative unit of the seis- } \\
\text { mic unit } 3 \text { b. Onlap on the } \\
\text { flanks of the volcanic seismic } \\
\text { unit } V_{\text {indiff }} \\
\text { 3b: sub-parallel to prograd- } \\
\text { ing seismic reflectors. Correl- } \\
\text { ative of the seismic unit } 3 \text { a. } \\
\text { H1:discontinuous to chaotic } \\
\text { seismic reflectors. } \\
\text { H2: discontinuous to chaotic } \\
\text { seismic reflectors. }\end{array}$ & $\begin{array}{l}\text { Vindiff: undifferentiated } \\
\text { acoustic volcanic basement, } \\
\text { genetically related with the } \\
\text { Citara tuffs. } \\
\text { Pls: relict Pleistocene pro- } \\
\text { grading wedge. } \\
\text { 1a: first seismic unit of the } \\
\text { basin filling in the western } \\
\text { Ischia offshore. } \\
\text { 1b: shelf margin wedge over- } \\
\text { lying the volcanic acoustic } \\
\text { basement. } \\
\text { 2: second seismic unit of the } \\
\text { basin filling in the western Is- } \\
\text { chia offshore. } \\
\text { 3a: third seismic unit of the } \\
\text { basin filling in the western } \\
\text { Ischia offshore. } \\
\text { 3b: shelf margin wedge, } \\
\text { cropping out at the sea bot- } \\
\text { tom. Probable occurrence of } \\
\text { algal mattes at the top of the } \\
\text { unit. } \\
\text { H1: hummocky deposits em- } \\
\text { placed during a first phase in } \\
\text { the western Ischia offshore. } \\
\text { H2: hummocky deposits } \\
\text { emplaced during a second } \\
\text { phase in the western Ischia } \\
\text { offshore. }\end{array}$ & $\begin{array}{l}\text { TCT Citara Tuffs: ash tuffs } \\
\text { and lapilli-rich ash tuffs. } \\
\text { TPR Punta delle Pietre Rosse } \\
\text { tuffs: ash tuffs supported by } \\
\text { matrix. } \\
\mathbf{g}_{2} \text { present and recent beach } \\
\text { deposits: medium-coarse-to- } \\
\text { fine-grained sands with peb- } \\
\text { ble gravels. } \\
\text { sgs submerged beach depos- } \\
\text { its: } \\
\text { rounded gravels, sandy grav- } \\
\text { els and coarse-grained sands. }\end{array}$ \\
\hline
\end{tabular}




\begin{tabular}{|c|c|c|c|c|c|}
\hline Location & $\begin{array}{c}\text { Coastal } \\
\text { morphology }\end{array}$ & $\begin{array}{l}\text { Seismic } \\
\text { units }\end{array}$ & Seismic facies & Geologic interpretation & $\begin{array}{l}\text { Coastal stratigraphy } \\
\text { (SBRANA et alii 2011) }\end{array}$ \\
\hline $\begin{array}{l}\text { Panza } \\
\text { (south- } \\
\text { western } \\
\text { Ischia) }\end{array}$ & $\begin{array}{l}\text { Punta dello } \\
\text { Schiavo } \\
\text { coastal cliff }\end{array}$ & $\begin{array}{l}\text { Six seismic } \\
\text { units (Vindiff, } \\
\text { LST, TST, } \\
\text { HST, Sl1, Sl2) }\end{array}$ & $\begin{array}{l}\text { Vindiff: Acoustically trans- } \\
\text { parent seismic facies } \\
\text { LST: Parallel to oblique seis- } \\
\text { mic reflectors. } \\
\text { TST: Sub-parallel to slightly } \\
\text { inclined seismic reflectors. } \\
\text { HST: Sub-parallel seismic } \\
\text { reflectors. } \\
\text { Sl1: Oblique seismic reflec- } \\
\text { tors. } \\
\text { S12: Oblique seismic reflec- } \\
\text { tors. }\end{array}$ & $\begin{array}{l}\text { Vindiff: Undifferentiated } \\
\text { volcanic acoustic basement, } \\
\text { genetically related with the } \\
\text { Scarrupo di Panza pyroclas- } \\
\text { tic deposits. } \\
\text { LST: Aggradational/ } \\
\text { progradational sequence, } \\
\text { interpreted as the lowstand } \\
\text { system tract (late Quaternary } \\
\text { depositional sequence). } \\
\text { TST: Retrogradational seis- } \\
\text { mic sequence interpreted as } \\
\text { the transgressive system tract } \\
\text { (late Quaternary depositional } \\
\text { sequence). } \\
\text { HST: Aggradational seismic } \\
\text { sequence interpreted as the } \\
\text { highstand system tract (late } \\
\text { Quaternary depositional se- } \\
\text { quence). } \\
\text { Sl1: Recent slope deposits } \\
\text { (sequence 1). } \\
\text { Sl2: Recent slope deposits } \\
\text { (sequence 2). }\end{array}$ & $\begin{array}{l}\text { SUN }_{\mathbf{b}} \text { Scarrupo di Panza py- } \\
\text { roclastic deposits: trachytic } \\
\text { grey tuffs. } \\
\text { fbc coastal cliff toe deposits } \\
\text { blocks lava and tuff blocks } \\
\text { with gravelly-sandy matrix. } \\
\text { pss-proximal inner shelf de- } \\
\text { posits - sands } \\
\text { medium-to-fine-grained } \\
\text { sands and litho-bioclastic } \\
\text { sands. }\end{array}$ \\
\hline
\end{tabular}

Previous studies have referred these hummocky topographies to catastrophic volcaniclastic gravity flows, namely the debris avalanches, developed both in subaerial and subaqueous environments (SIEBERT, 1984; MASSON et alii, 1993; Orton, 1996; GARDNER et alii, 1999; LeE et alii, 1999; Ui et alii, 2000; CHIocci \& DE ALteriss, 2006). From time to time, the volcanic collapse may produce large rock and ash avalanches, travelling at high speeds down valleys. Important triggering causes of these events are represented from eruptions and earthquakes (SIEBERT, 1984; ViOLANTE et alii, 2003). As discussed by previous authors (VIOLANTE et alii, 2003) and on the contrary of what documented in southern Ischia (CHIOcci \& DE ALTERIIS, 2006) the correlation between the landslide deposits occurring on land and the hummocky deposits offshore northern Ischia lacks of a failure scarp in the north-western rim of the Epomeo Mount. The resurgence pattern of Ischia (Acocella \& Funiciello, 1999; TiBaldi \& Vezzoli, 2000) has controlled the occurrence of significant volcano-tectonic stresses involving the north-western Epomeo flanks. During the corresponding phases of geomorphologic slope re-modeling the failure scarp was related to the hummocky deposits of the northern sector. The monocline structure of the Epomeo Mount was instead uplifted with a corresponding increase in dip southwards, triggering for the catastrophic collapse of southern Ischia known as Ischia Debris Avalanche (IDA; Chiocci \& DE AlteriIs, 2006). Moreover, the emplacement of hummocky deposits offshore north-western Ischia should be strongly controlled by seismicity ranging in age from 470-460 B.C. up to 1883, controlling the emplacement of important landslides located onshore in the Epomeo Mount, Casamicciola, Forio and Lacco Ameno (Alessio et alii, 1996; Baratta, 1901; Buchner, 1986; Covelli, 1828; Cubellis, 1987; Cubellis \& Luongo, 1998; De Vita et alii, 2006; Mele \& Del Prete, 1998; Palmieri, 1881; RitTmann \& GotTIni, 1980).

Cyclical slope instabilities at Ischia and related landslide deposits have been studied in detail (DE VITA et alii,
2006). Four main phases have been suggested for the landslide generation at Ischia. During the first phase debris flow deposits have been described in the area between Mt. Trippodi and Costa Sparaina, whose upper boundary is represented by the Cannavale Tephra (2.9 ky; DE VITA et alii, 2006). During the second phase landslide deposits have been emplaced mainly in the Succhivo area, underlying the Chiarito Tephra, which has been erupted in the area of Panza (Gialanella, 1998; De Vita et alii, 2006). These deposits are represented by debris flows interlayered with alluvial deposits. During a third phase a large variety of landslide deposits has been identified and supposed to be interstratified with primary volcanic deposits in the areas of Succhivo, Mt. Trippodi, Candiano, Barano and Vateliero (DE VITA et alii, 2006). A fourth phase of landslide emplacement has been suggested by debris avalanche and debris flow deposits, genetically related with the Cretaio Tephra. These phases have been dated back respectively between 5.5 and $2.9 \mathrm{ky}$, around $2.9 \mathrm{ky}$, between 2.6 and $2.3 \mathrm{ky}$ and between 2.3 and 1.9 ky (DE ViTA et alii, 2006). Despite such a precise characterization of landslides in the Ischia island onshore based on detailed volcanological studies, there are not still enough elements to carry out a precise dating of the hummocky deposits, namely $\mathrm{H} 1$ and $\mathrm{H} 2$, recognized in the seismic sections studied in this paper, also due to the lacking of cores drilling the upper part of the hummocky deposits of the sequence H2. This will represent a possible task for a future study. Such a detailed tephrostratigraphic study has been carried out in southern Ischia Island, where a dense network of cores has been studied based on tephrostratigraphy (DE AlteriIs et alii, 2010).

The obtained seismo-stratigraphic results have been compared with the data on the submerged coastal geology shown in the same areas or in adjacent areas through underwater geological survey (MoNTI, 2011; SBRANA et alii, 2011). A geological section constructed in the submerged area adjacent to Punta del Soccorso has shown the articulated morphology of the detritic deposits composed of 
blocks of the Epomeo Green Tuffs (MonTI, 2011). Abrasion terraces have been singled out at water depths of 3 and $5 \mathrm{~m}$ bsl. A geological section constructed in the Punta Imperatore coastal cliff has shown different morpho-stratigraphic elements, consisting of a sea notch located at water depths of $2.5 \mathrm{~m}$ bsl, abrasion terraces located respectively at water depths of 5 and $10 \mathrm{~m}$ bsl and toe of cliff deposits consisting of gravels and pebbles (MonTI, 2011).

\section{CONCLUSIONS}

The tracts of rocky coasts of the Ischia Island show a noteworthy articulation and complexity due to the complex volcano-tectonic and geomorphologic evolution of the island, during which important landslides occurred (Calcaterra et alii, 2003; Del Prete \& Mele, 2006). In the Ischia Island the distribution of the landslides shows a correspondence and repetition in different physiographic domains (coastal cliffs, structural slopes, litho-structural slopes, incision axes related to the drainage network). In some cases, main sectors of the Ischia Island have been affected by complex landslides, involving both subaerial and subaqueous environments (ORTOLANI et alii, 1989; 1990; Guadagno \& Mele, 1992; Mele \& Del Prete, 1998; Chiocci \& de Alteriss, 2006; Del Prete \& Mele, 2006; Di Nocera et alii, 2007).

The coastal cliffs (CASTiglioni, 1979; SunAmura, 1992; Carobene, 2004; Pranzini, 2004; Strahler, 2015) resulted from the erosion of rocks, from semi-coherent to coherent, through the wave action and represent dipping seawards rocky walls. The coastal cliffs may be distinguished as active or inactive, depending on the wave action directly carving the toe-of-slope. In the study area the active coastal cliffs, which consist of rocky outcrops lacking of a sedimentary cover, turn into inactive sea cliffs through the deposition of superimposed detritic cones at the toeof-slope. The evolution of the whole cliff surface is mainly controlled by the erosional action of the sea at the toeof-slope through its scouring and the consequent gravitational mass movements.

The rocks constituting the high coastal cliffs of the Ischia Island may be distinguished in lavas, pyroclastic and detritic deposits (Del Prete \& Mele, 1999). Both the lavas and the detritic deposits are taken back to an equivalent and continuous medium (HoEk \& Brown, 1997) due to the random distribution of the fractures in the lavas and the chaoticity of the detritic deposits. However, the coastal cliffs facing on the sea, if involved in instability processes may be hazardous, also due to the occurrence of coastal infrastructures located in correspondence with the sea cliff edges, which tend to progressively retreat.

On the contrary, sandy beaches occur mainly in correspondence of the river mouths, where a large amount of sediments is supplied, which the currents and tides shift towards the shoreline, forming long littorals. Important beach systems occur in the Ischia Island, some of which, being affected by erosion, have been studied for artificial beach nourishments, such as the Maronti beach, to the south (Marsella et alii, 2001).

A different geologic evolution of the coastal sectors of Ischia Island may be suggested based on the seismic units deposited off low sandy sectors and high tuff coastal cliffs. In the high tuff coastal cliff of southern (Suc- chivo) and south-western sectors (Panza) the geologic evolution has been controlled by the deposition of thick volcanic seismic units, well detected in seismic profiles. In the Succhivo sector these units are genetically related with the Sant'Angelo tuffs, whose age established through $\mathrm{K} /$ Ar dating is 19-20,6 +/- 1,2 ky (Poli et alii, 1987). These tuffs have been probably erupted from a tuff cone located in the Punta del Chiarito offshore. In the Panza sector these volcanic units are genetically related with the Scarrupo di Panza pyroclastic deposits, whose age has not precisely established by modern volcanological studies, and represented by trachytic grey tuffs. The occurrence of erosional retreat of both the Succhivo and Panza coastal cliffs during the late Quaternary since recent times is suggested by the development of sea cliff toe deposits, detected through underwater geological survey and formed as belts parallel to the cliffs. In the Succhivo and Panza sectors these deposits consist of lava and tuff blocks with a gravelly-sandy matrix. While at Succhivo the submerged beach deposits, represented by gravels and sands, occur, at Panza they are lacking and proximal-inner shelf deposits outcrop along the sea bottom, composed of mediumto-fine-grained sands and litho-bioclastic sands.

In correspondence with the sandy beaches of Ischia harbor ("Spiaggia degli Inglesi") and Forio d'Ischia ("Cava dell'Isola") the volcanological processes have controlled the deposition of volcanic seismic units, representing the acoustic substratum of well developed sedimentary basins (Ischia harbor basin and Forio basin). At the Ischia harbor the volcanic unit is genetically related with the Ischia Porto spatter, composed of scoriaceous trachytic breccias. At Forio d'Ischia the volcanic acoustic basement is genetically related with the Citara tuffs, composed of ash tuffs and lapilli-rich ash tuffs. While the basin filling of the Ischia harbor is characterized by four main seismic units, composed of marine deposits, probably Late Pleistocene to Holocene in age, the basin filling of Forio d'Ischia is composed of three main seismic units, having correlative units on the continental shelf. In both the areas at least two phases of significant submarine sliding occurred after the basin filling, evidenced by two distinct bodies of hummocky deposits, separated by a parallel reflector, probably corresponding with a main detachment surface. In the Forio offshore these bodies were buried by shelf margin prograding wedges, deposited in coastal and marine environments during the Late Pleistocene-Holocene.

\section{AcKNowledgments}

I wish to thank Dr. Lucia Monti (Scientific Responsible of the CARG Project, Region Campania, Via A. De Gasperi, 80133, Napoli) for making available the Sparker seismic sections interpreted in this paper. I thank also the reviewers of the paper, strongly improving the manuscript. I thank Prof. William Cavazza, Editor in Chief of the Italian Journal of Geosciences, for his suggestions and support during the publication of this manuscript.

\section{REFERENCES}

Abellan A., Calvet J., Vilaplana J.M. \& Blanchard J. (2010) Detection and spatial prediction of rock falls by means of terrestrial laser scan ner monitoring. Geomorphology, 119(3-4), 162-171.

Acocella V., Funiciello R. (1999) The interaction between regional and local tectonics during resurgent doming: the case of the island of Ischia, Italy. Journal of Volcanology and Geothermal Research, 88, 109-123. 
Acocella V., Funiciello R. \& Lombardi S. (1997) Active tectonics and resurgence at Ischia Island (southern Italy). Il Quaternario, 10 427-432.

Acocella V., Salvini F., Funiciello R. \& Faccenna C. (1999) The role of transfer structures on volcanic activity at Campi Flegrei (Southern Italy). Journal of Volcanology and Geothermal Research, 91, 123-139.

Aiello G. \& Marsella E. (2013) The stratigraphic setting of continental shelves of Southern Italy investigated through seismic stratigraphy: techniques, methodologies and case histories from Campania and Basilicata offshore. Horizons in Earth Science Research, 10, 1-102.

Aiello G. \& Marsella E. (2014) The Southern Ischia canyon system: examples of deep sea depositional systems on the continental slope off Campania (Italy). Rendiconti Online della Società Geologica Italiana, 32, 28-37, doi: 10.3301/ROL.2014.145.

Aiello G. \& Marsella E. (2015a) Interactions between Late Quaternary volcanic and sedimentary processes in the Naples Bay, southern Tyrrhenian sea. Italian Journal of Geosciences, 134(1), doi: 10.3301/ IJG.2014.56.

Aiello G. \& Marsella E. (2015b) Geological evolution of the Ischia volcanic complex (Naples Bay, Tyrrhenian sea) based on submarine seismic reflection profiles. Proceedings Volcanic Rocks and Soils, Rotonda T . et al. (Eds.), Taylor and Francis Group, London, ISBN 978-1-138-02886-9, pp. 305-312.

Aiello G., Marsella E. \& SAcchi M. (2000) Quaternary structural evolution of Terracina and Gaeta basins (Eastern Tyrrhenian margin, Italy). Rendiconti Lincei, 11, 41-58.

Aiello G., Budillon F., Cristofalo G., D’Argenio B., de Alteriis G., De lauro M., Ferraro L., Marsella E., Pelosi N. Sacchi M. \& Tonielli R. (2001) Marine geology and morphobathymetry in the Bay of Naples (South-eastern Tyrrhenian sea, Italy). In: Structures and Processes of Mediterranean Ecosystems (FARANDA F.M., Guglielmo L., Spezie G., Eds.), Springer Verlag Italy, $1^{\circ}$ Convegno Nazionale delle Scienze del Mare, CONISMA sul Tema Diversità e Cambiamento, Ischia, 11-14 Novembre 1998, pp. 1-8.

Aiello G., Marsella E. \& Passaro S. (2009) Submarine instability processes on the continental slopes off the Campania region (Southern Tyrrhenian sea, Italy): the case history of the Ischia island (Naples Bay). Bollettino di Geofisica Teorica Applicata, 50, 193-207.

Aiello G., Marsella E. \& Passaro S. (2012) Stratigraphic and structural setting of the Ischia volcanic complex (Naples Bay, Southern Italy) revealed by submarine seismic reflection data. Rendiconti Lincei, 23, 387-408.

Aiello G., Di Fiore V., Marsella E. \& Passaro S. (2014) High resolution seismic data coupled to Multibeam bathymetry of Stromboli island collected in the frame of the Stromboli geophysical experiment: implications with the marine geophysics and volcanology of the Aeolian Arc volcanic complex (Sicily, Southern Tyrrhenian sea, Italy). Springerplus, 3, 232 doi: 10.1186/2193-1801-3-232.

Aiello G., Giordano L. \& Giordano F. (2016) High resolution seismic stratigraphy of the Gulf of Pozzuoli (Naples Bay) and relationships with submarine volcanic setting of the Phlegrean Fields volcanic complex. Rendiconti Lincei, 27(4), 775-801.

Alessio G., Esposito E., Ferranti L., Mastrolorenzo G. \& Porfido S. (1996) Correlazione tra sismicità ed elementi strutturali dell'Isola d'Ischia. Il Quaternario, 9(1), 303-308.

BARATTA M. (1901) I terremoti d'Italia. Ristampa anastatica, Fondi Editore.

Barra D., Cingue A., Italiano A. \& Scorziello R. (1992) La serie marina olocenica di Cafieri (Isola d'Ischia): implicazioni vulcano-tettoniche e geomorfologiche. Il Quaternario, 5(1), 17-26.

Bartole R., Savelli C., Tramontana M. \& Wezel F.C. (1983) Structural and sedimentary features in the Tyrrhenian margin off Campania, Southern Italy. Marine Geology, 55, 163-180.

Bozzano F., Mazzanti P., Prestininzi A. \& Scarascia Mugnozza G. (2010) Research and development of advanced technologies for landslide hazard analysis in Italy. Landslides, 7(3), 381-385.

Brown R.J., Orsi G. \& De Vita S. (2008) New insights into Late Pleistocene explosive volcanic activity and caldera formation on Ischia (southern Italy). Bulletin of Volcanology, 70, 583-603.

BRuno P.P.G. (2004) Structure and evolution of the Bay of Pozzuoli (Italy) using marine seismic reflection data: implications for collapse of the Campi Flegrei caldera. Bulletin of Volcanology, 66(4), 342-355.
Bruno P.P.G., De AlteriIs G. \& Florio G. (2002) The western undersea section of the Ischia volcanic complex (Italy, Tyrrhenian sea). Geophysical Research Letters, 29(9), doi: 10.1029/2001GL013904.

BuchNER G. (1986) Eruzioni vulcaniche e fenomeni vulcano-tettonici di età preistorica nell'Isola d'Ischia. Publication Centre J. Berard Naples, 7, 145-188.

Calcaterra D., Del Prete S. \& Mele R. (2003) L'influenza dei fenomeni franosi sugli insediamenti costieri del distretto flegreo (Campania, Italia). Proc. Internat. Conf. CITTAM 2003 "The requalification of Mediterranean coasts among tradition, development and sustainability", Naples, June 26-28, Arte tipografica Editore, 524-534, Napoli, Italy.

CAROBEnE L. (2004) Uplifted coastlines and marine terraces. In: Crescenti V., D’Offizi S., Merlino S., Sacchi L. (Eds.) Geology of Italy. Società Geologica Italiana, Special Volume, Roma, pp. 174-177.

Carminati E., Wortel J.R., Spakman W. \& Sabadini R. (1998) The role of slab detachment processes in the opening of the western central Mediterranean basins. Some geological and geophysical evidence. Earth Planetary Science Letters, 160, 651-665.

Casciello E., Cesarano M. \& Pappone G. (2006). Extensional detachment faulting on the Tyrrhenian margin of the southern Apennines contractional belt (Italy). Journal of the Geological Society of London, 163, 617-629.

Castiglioni G.B. (1979) Geomorfologia. Hoepli Editore, Milano, Italy.

Chiesa S., Cornette Y., Forcella F., Gillot P.Y., Pasouarè G. \& Vezzoli L. (1985) Carta geologica dell'isola d'Ischia. CNR, Progetto Finalizzato Geodinamica, Roma, Italy.

Chiesa S., Civetta L., De Lucia M., Orsi G. \& Poli S. (1987) Volcanological evolution of the island of Ischia. In: Di Girolamo P. et alii (Eds.) The Volcaniclastic Rocks of Campania (Southern Italy). Rendiconti Acc. Sci. Fis. e Mat. In Napoli, Special Issue (1987), pp. 69-83.

Chiocci F.L., Ercilla G. \& Torres J. (1997) Stratal architecture of Western Mediterranean Margins as the result of the stacking of Ouaternary deposits below glacio-eustatic fluctuation base-level. Sedimentary Geology, 116(1-2), 157-158.

Chiocci F.L. \& DE Alteris G. (2006) The Ischia debris avalanche: first clear submarine evidence in the Mediterranean of a volcanic island prehistorical collapse. Terra Nova, 18(3), 202-209.

Cinque A., Aucelli P.P.C., Brancaccio L., Mele R., Milia A., Robustell G., Romano P., Russo F., Russo M., Santangelo N. \& Sgambati D. (1997) Volcanism, tectonics and recent geomorphological change in the Bay of Napoli. Supplementi Geografia Fisica Dinamica Quaternaria, 3, 123-141.

Civetta L., Gallo G. \& Orsi G. (1991) Sr and Nd isotope and trace element constraints on the chemical evolution of the magmatic system of Ischia (Italy) in the last $55 \mathrm{ky}$. Journal of Volcanology and Geothermal Research, 46, 213-230.

Clark A.R., Moore R. \& Palmer J.S. (1996) Slope monitoring and early warning systems: application to coastal landslides on the south and east coast of England, UK. Proceedings of the $7^{\text {th }}$ International Symposium on Landslides, Trondheim, 1531-1539.

Cloetingh S., Beekman F., Ziegler P.A., van Wees J.D. \& Sokoutis D. (2008) Post-rift compressional reactivation potential of passive margins and extensional basins. Geological Society of London, Special Publications, 306, 27-70.

Conti A., Bigi S., Cuffaro M., Doglioni C., Scrocca D., Muccini F., Cocchi L., Ligi M. \& Bortoluzzi G. (2017) Transfer zones in an oblique back-arc basin setting: Insights from the Latium Campania segmented margin (Tyrrhenian sea). Tectonics, 36(1), 78-107.

Corradi N., Ferrari M., Giordano F., Giordano R., Ivaldi R. \& Sbrana A. (2009) SAM-source and D-seismic system: the Use in Marine Geological Mapping CARG and PNRA Projects. 27 $7^{\text {th }}$ IAS Meeting of Sedimentologists, Alghero (Italy), pp. 85-90, Extended Abstract.

Covelli N. (1828) Cenno sul tremuoto d'Ischia avvenuto il 2 febbraio 1828. In: "Il Pontano", 1828, anno I, 82-92.

Crisci G.M., De Francesco A.M., Mazzuoli R., Poli G. \& Stanzione D. (1989) Geochemistry of recent volcanics of Ischia Island, Italy: Evidences for fractional crystallization and magma mixing. Chemical Geology, 78(1), 15-33.

Cruden D.M. \& VARnes D.J. (1996) Landslide types and processes. In: TURNER A.K., SCHUSTER R.L. (Eds.) Landslides: investigation and mitigation (Special Report). Washington, DC, USA: National Research Council, Transportation and Research Board Special Report 247, 36-75. 
Cubellis E. (1987) Il terremoto di Casamicciola del 28 luglio 1883: analisi degli effetti, modellizzazione della sorgente ed implicazioni sulla dinamica in atto. Bollettino Società Naturalisti in Napoli, 64, 157-186.

Cubellis E., Luongo G. (1998) Sismicità storica dell'Isola d'Ischia. Il terremoto del 28 luglio 1883. Campo macrosismico e studio della sorgente. Analisi sismo-tettonica. In: Il terremoto del 28 luglio 1883 a Casamicciola nell'Isola d'Ischia, Servizio Sismico Nazionale, 49-116.

D’Argenio B., Aiello G., de Alterits G., Milia A., Sacchi M., Tonielli R., Budillon F., Chiocci F.L., Conforti A., De Lauro M., D’Isanto C. Esposito E., Ferraro L., Insinga D., Marsella E., Molisso F., Morra V., Passaro S., Pelosi N., Porfido S. Raspini A., Sacchi M., Toniell R. \& Violante C. (2004) Digital Elevation Model of the Naples Bay and surrounding areas, Eastern Tyrrhenian sea, Italy. In: Mapping Geology in Italy, Atlante di Cartografia Geologica, Convegno Internazionale "Firenze 2004".

DE AlteriIs G. \& Violante C. (2009) Catastrophic landslides off Ischia volcanic island during prehistory. In: Violante C. (Ed.) Geohazard in rocky coastal areas. Special Publication Geological Society of London, 322, 73-104.

de AlteriIs G., Insinga D.D., Morabito S., Morra V., Chiocci F.L., Terrasi F., Lubritto C., Di Benedetto C. \& Pazzanese M. (2010) Age of submarine debris avalanches and tephrostratigraphy offshore Ischia Island, Tyrrhenian Sea, Italy. Marine Geology, 278, 1-18.

Deino A.L., Orsi G., De Vita S. \& Piochi M. (2004) The age of the Neapolitan Yellow Tuff caldera-forming eruption (Campi Flegrei caldera, Italy) assessed by ${ }^{40} \mathrm{Ar} /{ }^{39} \mathrm{Ar}$ dating method. Journal of Volcanology and Geothermal Research, 91(2-4), 269-301.

Del PRETe S. \& MeLe R. (1999) L'influenza dei fenomeni di instabilità di versante nel quadro morfoevolutivo della costa dell'Isola d'Ischia (Campania). Bollettino della Società Geologica Italiana, 118, 339 360.

Del Prete S. \& Mele R. (2006) Il contributo delle informazioni storiche per la valutazione della propensione al dissesto nell'Isola d'Ischia (Campania). Rendiconti Società Geologica Italiana, 2, nuova serie, $29-47$

Della Seta M., Marotta E., Orsi G., De Vita S., Sansivero F. \& Fredi P. (2012) Slope instability induced by volcano-tectonics as an additional source of hazard in active volcanic areas: the case of Ischia island (Italy). Bulletin of Volcanology, 74(1), 79-106.

De Vita S., Sansivero F., Orsi G. \& Marotta E. (2006) Cyclical slope instabilities and volcanism related to volcano-tectonism in resurgent calderas: the Ischia Island (Italy) case study. Engineering Geology, 86, 148-165.

De Vita S., Di Vito M.A., Gialanella C. \& Sansivero F. (2013) The impact of the Ischia Porto Tephra eruption (Italy) on the Greek colony of Pithekoussai. Quaternary International (2013), http://dx.doi. org/10.1016/j.quaint.2013.01.002.

Di Girolamo P., Ghiara M.R., Lirer L., Munno R., Rolandi G. \& Stanzione D. (1984) Vulcanologia e petrologia dei Campi Flegrei. Bollettino della Società Geologica Italiana, 103, 349-370.

Di Nocera S., Matano F., Rolandi G. \& Rolandi R. (2007) Contributo agli aspetti geologici e vulcanologici del Monte di Vezzi (Isola d'Ischia) per lo studio degli eventi franosi dell'Aprile 2006. Italian Journal of Engineering Geology and Environment, 2, 27-49.

Doglioni C., Innocenti F., Morellato C., Procaccianti D. \& Scrocca D. (2004) On the Tyrrhenian sea opening. Memorie Descrittive della Carta Geologica d'Italia, 44, 147-164

Ducci A., Rittmann A., Segre A.G., Cirese E. \& Gioria C. (1967) Carta geologica d'Italia 183-184, Isola d'Ischia-Napoli. Roma, Servizio Geologico d'Italia, 1967

EdIL T. B. \& LE VAlLeJo L.E. (1980) Mechanics of coastal landslides and the influence of slope parameters. Engineering Geology, 16(1-2), 83-96.

Faccenna C., Mattei R., Funiciello R. \& Jolivet L. (1997) Styles of back-arc extension in the Central Mediterranean. Terra Nova, 9 126-130.

Faccenna C., Becker T.W., Lucente F.P., Jolivet L. \& Rossetti F. (2001) History of subduction and back-arc extension in the Central Mediterranean. Geophysical Journal International, 145, 809-820.

Ferranti L., Oldow J.S. \& SAcchi M. (1996). Pre-Quaternary deformation orogen-parallel extension in the Southern Apennine belt, Italy. Tectonophysics, 260, 247-325.

Forcella F., Gnaccolini L. \& Vezzoli L. (1981) I depositi piroclastici del settore sud-orientale dell'isola d'Ischia. Rivista Italiana Paleontologia Stratigrafia, 89, 1-35.
Gardner J.V., Prior D.B. \& Field M.E. (1999) Humboldt Slide - a large shear-dominated retrogressive slope failure. Marine Geology, 154, 323-338.

Gialanella C. (1998) Pithecusa: una fattoria greca arcaica a Punta Chiarito. Ass. Internazionale Amici di Pompei, Archeologia e Vulcanologia in Campania, 87-96.

Gillot P.Y., Chiesa S., Pasouarè G. \& Vezzoli L. (1982) 33.000 yr. K/ Ar dating of the volcano-tectonic horst of the isle of Ischia, Gulf of Naples. Nature, 229, 242-245.

Giordano F., Mattei G., Milia A. \& Torrente M.M. (2013) Quaternary faulting off Ischia Island (Italy): preliminary results. Rendiconti online della Società Geologica Italiana, 29, I-IV.

Guadagno F.M. \& Mele R. (1992) Earthquake-induced landslides in the island of Ischia (Southern Italy). Proc. Sixth International Symposium on the Landslides, New Zealand, 10-14 February 1992.

Guadagno F.M. \& Mele R. (1995) La fragile isola d'Ischia. Geologia Applicata e Idrogeologia, 30(1), 177-187.

Hall J.W., Lee E.M. \& Meadowcroft I.C. (2000) Risk-based benefit assessment of coastal cliff protection. Proceedings of the Institution of Civil Engineers - Water and Maritime Engineering, 142(3), 127-139.

Hoek E. \& Brown E.T. (1997) Practical estimates on rock mass strength. International Journal of Rock Mechanics \& Mining Sciences \& Geomechanics Abstracts, 34(8), 1165-1186.

Iadanza C., Trigila A., Vittori E. \& Serva L. (2009) Landslides in coastal areas of Italy. Geological Society of London Special Publications, 322, 121-141.

Insinga D., Molisso F., Lubritto C., SAcchi M., Passariello I., Morra V. (2008) The proximal marine record of Somma-Vesuvius volcanic activity in Naples and Salerno Bays, Eastern Tyrrhenian sea, during the last 3 kyrs. Journal of Volcanology and Geothermal Research, 177, 170-186.

Lastras G., Canals M., Urgeles R., De Batist M., Calafat M. \& Casamor J.L. (2004) Characterization of the recent BIG'95 debris flow deposit on the Ebro margin, Western Mediterranean Sea, after a variety of seismic reflection data. Marine Geology, 213(1-4), 235-255.

Lee H.G., Locat J., Dartnell P. \& Wong F. (1999) Regional variability of slope stability: application to the Eel margin, California. Marine Geology, 154, 305-321.

Luongo G., Cubellis E. \& Obrizzo F. (1997) Ischia: storia di un'isola vulcanica. Liguori Editore, Napoli.

Lustrino M. \& WiLson M. (2007) The circum-Mediterranean anorogenic Cenozoic igneous province. Earth Science Reviews, 81, 1-65.

Malinverno A. \& RYAN W.B.F. (1986) Extension in the Tyrrhenian sea and shortening in the Apennines as a result of arc migration driven by sinking of the lithosphere. Tectonics, 5, 227-245.

MARIANI M. \& Prato R. (1988). I bacini neogenici del margine tirrenico: approccio sismico-stratigrafico. Memorie della Società Geologica Italiana, 41, 519-531.

Marsella E., Budillon F., de Alterits G., De Lauro M., Ferraro L., Molisso F., Monti L., Pelosi N., Toccaceli R.M., Tonielli R. \& Violante C. (2001) Indagini geologiche, geofisiche e sedimentologiche dei fondali della Baia dei Maronti (Isola d'Ischia). Libreria L'Ateneo Due di Salvatore Pironti, Consiglio Nazionale delle Ricerche, Istituto di Ricerca "Geomare Sud", Napoli, 77 pp.

Masson D.G., Hugget Q.J. \& Brunsden D. (1993) The surface texture of the Saharan debris flow and some speculations on submarine debris flow processes. Sedimentology, 40, 583-589.

Mattei M., D’Agostino N., Zananiri I., Kondopoulou D., Pavlides S. \& SPATHARAS V. (2004) Tectonic evolution of fault-bounded continental blocks: Comparison of paleomagnetic and GPS data in the Corinth and Megara basins (Greece). Journal of Geophysical Research, 109, B02106, doi:10.1029/2003JB002506.

Mattera M. (1995) Valutazione del rischio vulcanico nell'isola d'Ischia. Tesi di Laurea, Università degli Studi di Napoli Federico II.

Mele R. \& Del Prete S. (1998) Fenomeni di instabilità dei versanti in Tufo Verde di Monte Epomeo (isola d'Ischia - Campania). Bollettino della Società Geologica Italiana, 117(1), 93-112.

Milia A. (2000) The geomorphology of the Naples Bay continental shelf (Italy). Geografia Fisica Dinamica Quaternaria, 22, 73-78.

Milia A. \& Torrente M.M. (2000) Fold uplift and synkinematic stratal architectures in a region of active transtensional tectonics and volcanism, eastern Tyrrhenian Sea. GSA Bulletin, 112(10), 1531-1542. 
Milia A. \& Torrente M.M. (2003) Late Quaternary volcanism and transtensional tectonics in the Bay of Naples, Campanian continental margin, Italy. Contributions to Mineralogy and Petrology, 79, 49-65.

Moeller S., Grevemeyer I., Ranero C.R., Berndt C., Klaeschen D., Sallares V., Zitellini N. \& De Franco R. (2013) Early-stage rifting of the northern Tyrrhenian Sea Basin: results from a combined wide-angle and multichannel seismic study. Geochemistry, Geophysics, Geosystems, 14(8), 3032-3052.

Molisso F. Insinga D., Marzaioli F., Sacchi M. \& Lubritto C. (2010) Radiocarbon dating versus volcanic event stratigraphy: age modelling of Quaternary marine sequences in the coastal region of the Eastern Tyrrhenian sea. Nuclear Instruments and Methods in Physics Research B, 268, 1236-1240.

Monti L. (2011) Isola d'Ischia. Guida geologico-ambientale. Regione Campania Assessorato Difesa del Suolo. Litografia Artistica Cartografica, Firenze, $356 \mathrm{pp}$ (with attached maps).

Oldow J.S., D’Argenio B., Ferranti L., Pappone G., Marsella E. \& SACCHI M. (1993) Large-scale longitudinal extension in the Southern Apennines contractional belt, Italy. Geology, 21, 1123-1126.

Orsi G., Gallo G., \& ZanCHI A. (1991) Simple-shearing block resurgence in caldera depressions. A model from Pantelleria and Ischia. Journal of Volcanology and Geothermal Research, 47(1-2), 1-11.

Orsi G., Piochi M., Campajola L., D’Onofrio A., Gialanella L. \& Terrasi F. (1996) ${ }^{14} \mathrm{C}$ geochronological constraints for the volcanic history of the island of Ischia (Italy) over the last 5,000 years. Journal of Volcanology and Geothermal Research, 71, 249-257.

Ortolani F., Pagliuca S. \& Toccaceli R.M. (1989) Geologia, geomorfologia e tettonica attiva di aree significative della Campania interessate da instabilità degli abitati. Atti del Convegno "Studio centri abitati instabili", Portonovo di Ancona.

Ortolani F., Pagliuca S. \& Toccaceli R.M. (1990) Rischio ambientale della Piana Campana. Necessità di integrazione della legislazione alla vulnerabilità del territorio (riassunto). Memorie della Società Geologica Italiana, 45, 389-391.

Orton G.J. (1996) Volcanic environments. In: Reading H.J. (Ed.) Sedimentary environments: process, facies and stratigraphy. Blackwell Science, 485-556.

Palmieri L. (1881) Sul terremoto di Casamicciola del 4 marzo 1881. Rendiconti Acc. Sc. Fis. e Mat. in Napoli. Fasc. 4.

Passaro S., De AlteriIs G. \& Sacchi M. (2016) Bathymetry of Ischia Island and its offshore (Italy), scale 1:50.000. Journal of Maps 12:1, 152-159, DOI:10.1080/17445647.2014.998302.

Patacca E. \& Scandone P. (1989) Post-Tortonian mountain building in the Apennines: The role of passive sinking of a relic lithospheric slab. In: Boriani A., Bonafede M., Piccardo G., Vai G. (Eds.) The lithosphere in Italy, Advances in Earth Science Research, Accademia Nazionale dei Lincei, Roma, 157-176.

Patacca E. \& Scandone P. (2007) Geology of the Southern Apennines. Bollettino della Società Geologica Italiana, 7, 75-119.

Poli S., Chiesa S., Gillot P.Y., Gregnanin A. \& Guichard F. (1987) Chemistry versus time in the volcanic complex of Ischia (Gulf of Naples, Italy): evidence of successive magmatic cycles. Contributions to Mineralogy and Petrology, 95(3), 322-335.

Poli S., Chiesa S., Gillot P.Y., Guichard F. \& Vezzoli L. (1989) Time dimensions in the geochemical approach and hazard estimation of a volcanic area: the isle of Ischia case (Italy). Journal of Volcanology and Geothermal Research, 36, 327-335.

Pranzini E. (2004) La forma delle coste. Geomorfologia costiera, impatto antropico e difesa dei litorali. Zanichelli Editore, Bologna, Italy.
Rittmann A. (1930) Geologie der Insel Ischia. Zeitr. Fur Vulkanol., 6, $1-265$.

Rittmann A. (1948) Origine e differenziazione del magma ischitano. Bull. Suisse Mineral. Petrogr., 28, 643-698.

Rittmann A., Gottini V. (1980) L'isola d'Ischia: Geologia. Bollettino del Servizio Geologico Italiano, 101, 131-274.

Rollet N., Déverchere J., Beslier M.O., Guennoc P., Rehault J.P., Sosson M. \& TRUfFERT C. (2002) Back arc extension, tectonic inheritance and volcanism in the Ligurian Sea, Western Mediterranean. Tectonics, 21(3), 6-1-6-23.

Sacchi M., Infuso S. \& Marsella E. (1994) Late Pliocene-Early Pleistocene compressional tectonics in offshore Campania (eastern Tyrrhenian sea). Bollettino di Geofisica Teorica Applicata, 36, 141-144.

Sacchi M., Insinga D., Milia A., Molisso F., Raspini A., Torrente M.M. \& CONFORTI A. (2005) Stratigraphic signature of the 79 AD event off the Sarno prodelta system, Naples Bay. Marine Geology, 222-223, 443-457.

Sacchi M., Alessio G., Aouino I., Esposito E., Molisso F., Nappi R., Porfido S. \& Violante C. (2009) Risultati preliminari della campagna oceanografica CAFE_07 - Leg 3 nei Golfi di Napoli e Pozzuoli, Mar Tirreno Orientale. Quaderni di Geofisica, 64, 1-26.

SARTORI R. (2003) The Tyrrhenian back-arc basin and subduction of the Ionian lithosphere. Episodes, 26(3), 217-221.

Sartori R., Torelli L., Zitellini N., Carrara G., Magaldi M. \& Mussoni P. (2004) Crustal features along a W-E Tyrrhenian transect from Sardinia to Campania margins (Central Mediterranean). Tectonophysics, 383(3-4), 171-192.

Sbrana A., Toccaceli R.M., Monti L., Faccenna C., Fulignati P., Giudetti G., Marianelli P., Deino A., Bravi S., D'Argenio B., Marsella E., Putignano M.L., de AlteriIs G., De Lauro M., Di Martino G., D’Isanto C., Giordano F., Innangi S., Passaro S., Scotto di Vettimo P., Tonielli R., Aiello G., Budillon F., Conforti A., Capodanno M., Molisso F. \& Ferraro L. (2011) Foglio geologico 464 Isola d'Ischia della Carta 1:25.000 dell'I.G.M. ISPRA (Servizio Geologico d'Italia), Regione Campania, Settore Difesa del Suolo, Geotermia e Geotecnica.

SIEBERT L. (1984) Large volcanic debris avalanches: characteristics of source areas, deposits and associated eruptions. Journal of Volcanology and Geothermal Research, 22, 163-197.

Strahler A. (2015) Fondamenti di geografia fisica. Edizione italiana a cura di Elvio Lavagna e Guido Lucamo. Zanichelli Editore, Bologna, Italy.

SunAmURA T. (1992) Geomorphology of rocky coasts. John Wiley and Sons, Chichester, USA.

Tibaldi A. \& Vezzoli L. (2000) Late Quaternary monoclinal folding induced by caldera resurgence at Ischia, Italy. In: ConsGrove J.W., AmeEn J.S. (Eds.) Forced Folds and Fractures. Geological Society of London, Special Publications, 169, 103-113.

ThieBEs B. (2012) Theoretical Background. In: Landslide Analysis and Early Warning Systems. Springer Theses (Recognizing Outstanding Ph.D. Research), Springer, Berlin, Heidelberg.

Ui T., TaKerada S. \& Yoshimoto M. (2000) Debris avalanches. In: SigURDSSON D. et alii (Eds.) Encyclopedia of Volcanoes. Academic Press., 617-626.

Vezzoli L. (1988) Island of Ischia. CNR, Quaderni De La Ricerca Scientifica, Roma, Italy.

Violante C., Budillon F., Esposito E., Porfido S. \& Vittori E. (2003) Submerged hummocky topographies and relations with landslides, northwestern flank of Ischia island, Southern Italy. Proceedings of the Int. Conf. Occurrence and Mechanisms of flow-like landslides in natural slopes, Sorrento, Italy, 309-315. 